\author{
К. О. ТАЛАЛАЄВ, В. С. ГОЙДИК, Р. С. ВАСТЬЯНОВ, А. В. ТОДОРОВА
}

\title{
ДИНАМІКА ЗМІН ЕПІДЕМІЧНОЇ СИТУАЦІї З ТУБЕРКУЛЬОЗУ В ОБЛАСТЯХ ПРИЧОРНОМОРСЬКОГО РЕГІОНУ ТА В УКРАЇНІ В ПЕРІОД 32006 ДО 2018 p.
}

\author{
Одеський національний медичний університет, м. Одеса, Україна
}

\begin{abstract}
Мета: проаналізувати епідемічну ситуацію з туберкульозу в Україні та, зокрема, в Причорноморському регіоні (Одеська, Миколаївська та Херсонська області) в період з 2006 до 2018 р. за показниками захворюваності на нові випадки та рецидиви туберкульозу, туберкульоз легень з бактеріовиділенням, мультирезистентний туберкульоз та ко-інфекцію туберкульоз+ВІЛ, а також поширеності та летальності від туберкульозу та ко-інфрекції туберкульоз+ВІЛ.

Матеріали і методи. Для проведення цього дослідження використано аналітично-статистичні матеріали щодо туберкульозу, оприлюднені на офріційному сайті Центру громадського здоров'я МОЗ України.

Результати. 32012 р. показник захворюваності на туберкульоз в Україні щороку знижувався в середньому на 4,2 \%. Проте в Одеській області в період з 2011 до 2018 р. захворюваність на туберкульоз зросла на 30,3 \%. Інтенсивний показник захворюваності на ко-інфекцію ТБ+ВІЛ в Україні збільшився на 21 \% в період 32011 до 2017 р. Зниження поширеності та летальності від туберкульозу в Україні спостерігають з 2006 до 2017 р. та 32012 до 2017 р. відповідно.

Висновки. 32011 до 2017 р. захворюваність на туберкульоз (нові випадки та рецидиви), туберкульоз легень з бактеріовиділенням, вперше діагностований туберкульоз, мультирезистентний туберкульоз та ко-інфекція туберкульоз+ВІЛ в Одеській, Миколаївській та Херсонській областях щороку перевищували відповідні середні показники по Україні.

У Причорноморському регіоні, за винятком Одеської області, та в Україні в цілому з 2012 до 2017 р. простежується тенденція до зниження летальності від туберкульозу.

Летальність від ко-інфекції туберкульоз+ВІЛ в Одеській та Миколаївській областях щороку перевищувала показник по України у середньому в 2,6 та 3,2 раза відповідно.
\end{abstract}

КЛЮЧОВІ СЛОВА: туберкульоз; бактеріовиділення; мультирезистентний туберкульоз; ко-інсрекція туберкульоз+ВІЛ; поширеність; летальність; Причорноморський регіон України.

Туберкульоз (ТБ) є захворюванням, яке вже впродовж тривалого часу займає своє місце серед 10 найрозповсюдженіших причин смерті в світі, а також є світовим лідером серед причин смерті інфекційного ґенезу, які спричинені одним інфекційним агентом (частота смерті від ТБ є вищою, ніж від ВІЛ/СНІДу) [11].

За даними Global Tuberculosis report 2018, у 2017 р. в світі було офріційно зареєстровано 1,3 млн випадків смерті від ТБ серед осіб із ВІЛнегативним статусом, та додатково 300 тис. випадків серед ВІЛ-позитивних осіб [10]. ТБ спостерігають в усіх країнах, здатен уражати чоловіків та жінок, осіб усіх вікових груп. Проте найчастіше він уражає працездатне населення, причому чоловіки хворіють частіше, ніж жінки. Відомо, що лише 5-15 \% людей, інфрікованих мікобактерією ТБ, в подальшому хворіють на ТБ, проте особливу групу ризику становлять особи з ураженнями імунної системи насамперед люди, які живуть 3 ВІЛ (ЛЖВ). Вважають, що ризик розвитку активного ТБ для ЛЖВ є в 20-30 разів вищим, ніж для людей із ВІЛ-негативними статусом.
Показник захворюваності на ТБ у світі в 2017 р. становив 133 випадки на 100 тис. населення. Абсолютне число нових зареєстрованих випадків ТБ становило 6,4 млн, число нових випадків ТБ серед ЛЖВ становило 464 633. При цьому масштаби епідемії широко варіюють серед різних регіонів. У 2017 р. у країнах із найвищим рівнем доходу (більшість країн Західної Європи, Канада, США, Нова Зеландія) захворюваність на ТБ становила < 10 випадків на 100 тис. населення.

Тим часом у більшості 330 країн, які визнані країнами з високим тягарем ТБ, цей показник становив 150-400 випадків на 100 тис. населення, і в незначній кількості таких країн, як Мозамбік, Філіппіни та Південна Африка, показник захворюваності на ТБ у 2017 р. перевищив 500 випадків на 100 тис. населення.

Загалом, у світі в 2017 р. було зареєстровано 558 тис. нових випадків рифрампіцинорезистентного ТБ (Рифр ТБ), серед яких 82 \% припадало на мультирезистентний ТБ (МРТБ). Так, у світі 3,5 \% нових зареєстрованих випадків ТБ та $18 \%$ випадків ТБ, що раніше лікували, припадало на

(с) К. О. Талалаєв, В. С. Гойдик, Р. С. Вастьянов, А. В. Тодорова, 2019 
Рифр ТБ/МРТБ. Варто зазначити, що більше 50 \% випадків Риф ТБ/МРТБ в осіб, які раніше лікувалися від ТБ, було зареєстровано в країнах колишнього Радянського Союзу.

У світових масштабах захворюваність на ТБ у період з 2000 до 2017 р. щороку знижувалася в середньому на 2 \%. Найбільш вражаючі результати щодо зниження захворюваності на ТБ у період 32013 до 2017 р. продемонстрували країни Європейського регіону (зниження захворюваності на $5 \%$ на рік), Африканського регіону (4\% на рік), Південна Афррика (4-8 \% на рік) та Російська Федерація (5 \% на рік).

Наразі завдяки поширенню ефективної протитуберкульозної хіміотерапії та антиретровірусної терапії (для хворих на ко-інфекцію ТБ і ВІЛ) спостерігають світову тенденцію до зниження летальності від ТБ. Так, показник летальності від ТБ на 100 тис. населення серед осіб із ВІЛ-негативним статусом щороку скорочувався в середньому на 3 \% протягом 2001-2017 рр. Варто зазначити, що за відсутності медикаментозного лікування 70 \% хворих на ТБ, в яких був встановлений позитивний результат бактеріоскопії мокротиння на кислотостійкі бактерії, та 20 \% хворих із негативним результатом бактеріоскопії, проте підтвердженим ТБ за результатами культурального дослідження, вмирали протягом 10 років.

Україна наразі не входить до переліку 30 країн із найвищим тягарем ТБ, проте її включено до переліку 30 країн із найбільшою кількістю випадків МРТБ. Мультирезистентний туберкульоз на сьогодні є глобальною проблемою охорони здоров'я. Для лікування нерезистентних фрорм ТБ рекомендують курс протитуберкульозними препаратами першої лінії (рифампіцин, ізоніазид, етамбутол, піразинамід), який триває 6 місяців. Ціна такого лікування складає 40 доларів США на особу, а його ефективність, відповідно до даних, що надходять до ВООЗ, становить близько 85 \%. Для порівняння, мінімальний курс лікування МРТБ триває 20 місяців, передбачає застосування більш токсичних та менш ефективних препаратів, вартість його може сягати 1000 доларів США на одну особу, а ефективність складає $55 \%$.

Незважаючи на те, що, за даними ДУ «Центр громадського здоров'я Міністерства охорони здоров'я України», у 2004 р. було зупинене зростання захворюваності та ТБ в Україні і починаючи 32007 р. показники його знижено, епідемічна ситуація з ТБ в Україні залишається проблемою загальнодержавного масштабу. Зумовлюється це тим, що ТБ є соціально небезпечною інфекційною хворобою, наслідки якої загрожують економіці та соціальній безпеці держави [7].

Мета дослідження: проаналізувати епідемічну ситуацію з туберкульозу в Україні в цілому та в Причорноморському регіоні в період з 2006 до
2018 р. за показниками захворюваності на нові випадки та рецидиви туберкульозу, туберкульоз легень з бактеріовиділенням, мультирезистентний туберкульоз та ко-інфекцію туберкульоз+ВІЛ, а також поширеності та летальності від туберкульозу та ко-інорекції туберкульоз+ВІЛ. Причорноморський регіон України, до якого ми відносимо Одеську, Миколаївську та Херсонську області, був обраний для порівняльної оцінки епідемічної ситуації з туберкульозу, зважаючи на економічні, географрічні, побутові соціальні особливості характеристики та особливості надання медичної допомоги в цьому регіоні.

Матеріали і методи. Для проведення дослідження використано аналітично-статистичні матеріали з ТБ, оприлюднені на офріційному сайті Центру громадського здоров'я МО3 України, a саме «Таблиці зі статистичними даними» за 2012 [1], 2013 [2], 2014 [3], 2016 [4], 2017 [5] рр., «Таблиці зі статистичними даними до аналітичностатистичного довідника «Туберкульоз в Україні» за 2015 р.» [6], а також основні показники 3 туберкульозу за 2018 р. порівняно з аналогічним періодом 2017 р. (відповідно до фрорми звітності № 8 «Звіт про захворювання на активний туберкульоз»), надані Центром медичної статистики МОЗ України [8].

Результати дослідження та їх обговорення. Аналіз статистичних даних з епідеміології ТБ в Україні за 2006-2018 рр. показав, що протягом цього періоду змінювався підхід до дослідження епідемічного процесу, що наразі призводить до певної мозаїчності наявних даних. Так, наприклад, з 2010 р. показник захворюваності на ТБ враховує не лише нові випадки (ВДТБ), а й рецидиви ТБ (РТБ); так само з 2011 р. інтенсивний показник захворюваності на ТБ із бактеріовиділенням розрахований включно з випадками рецидивів ТБ. Аналогічна ситуація простежується і 3 показником захворюваності на ко-інфекцію ТБ+ВІЛ.

У таблиці 1 наведено основні дані про захворюваність на ТБ серед усього населення України в період з 2006 до 2018 р. У таблицях 2-4 наведено відповідні дані в Причорноморському регіоні України - Одеській, Миколаївській та Херсонській областях.

Аналіз епідемічної ситуації з ТБ у період з 2011 до 2018 р. показав, що зростання захворюваності на вперше виявлений ТБ та рецидиви ТБ в Україні останній раз спостерігали в 2011 р., після чого цей показник щороку знижувався в середньому на 4,2 \%. При цьому дещо скептично слід ставитися до даних, які вказують на зниження захворюваності на ТБ в Україні з 2014 до 2018 р., адже в ці роки розрахунок інтенсивного показника захворюваності на кількість населення України проводили включно з тимчасово окупованими 
Таблиця 1. Захворюваність на всі форми активного туберкульозу, туберкульоз легень 3 бактеріовиділенням, мультирезистентний туберкульоз та туберкульоз у поєднанні зі СНІДом серед усього населення України в період з 2006 до 2018 р. (абс., на 100 тис. населення)

\begin{tabular}{|c|c|c|c|c|c|c|c|c|c|c|c|c|c|}
\hline \multirow{2}{*}{ Показник } & \multicolumn{13}{|c|}{ Роки } \\
\hline & 2006 & 2007 & 2008 & 2009 & 2010 & 2011 & 2012 & 2013 & 2014 & 2015 & 2016 & 2017 & 2018 \\
\hline $\begin{array}{l}\text { Захворю- } \\
\text { ваність } \\
\text { (ВДТБ+РТБ) }\end{array}$ & - & - & - & - & \begin{tabular}{|l|}
$35080^{* 1}$ \\
$(82,3)$
\end{tabular} & $\begin{array}{l}35767^{\star 2} \\
(78,4)\end{array}$ & $\begin{array}{l}36594^{* 2} \\
(80,5)\end{array}$ & $\begin{array}{l}35163^{* 2} \\
(77,5)\end{array}$ & $\begin{array}{l}30568^{* 2,7} \\
(71,2)\end{array}$ & $\begin{array}{l}30151^{\star 2,7} \\
(70,5)\end{array}$ & $\begin{array}{l}28800^{\star 2,7} \\
(67,6)\end{array}$ & $\begin{array}{l}27121^{\star 2,7} \\
(63,9)\end{array}$ & $\begin{array}{l}26321^{\star 2,7} \\
(62,3)\end{array}$ \\
\hline $\begin{array}{l}\text { ТБ легень } 3 \\
\text { бактеріовиді- } \\
\text { ленням (без } \\
\text { рецидивів) }{ }^{\star 2,3}\end{array}$ & 30,4 & 31,5 & 31,6 & 29,7 & 28,9 & 29,1 & 30,8 & 33,8 & 31,0 & - & - & $\begin{array}{l}12381 \\
(29,2)\end{array}$ & $\begin{array}{l}12456 \\
(29,5)^{\star}\end{array}$ \\
\hline $\begin{array}{l}\text { Нові випадки } \\
+ \text { рецидиви } 2,3 \\
\end{array}$ & - & - & - & - & - & $\begin{array}{l}15686 \\
(34,4)\end{array}$ & $\begin{array}{l}17205 \\
(37,9) \\
\end{array}$ & $\begin{array}{l}19473 \\
(37,9)\end{array}$ & $\begin{array}{l}17476 \\
(42,9) \\
\end{array}$ & $\begin{array}{l}17946 \\
(40,7) \\
\end{array}$ & $\begin{array}{l}17371 \\
(42,0) \\
\end{array}$ & $\begin{array}{l}15768 \\
(37,2) \\
\end{array}$ & $\mathrm{N} / \mathrm{A}$ \\
\hline ВДТБ ${ }^{* 2}$ & - & $\begin{array}{l}37095 \\
(79,8) \\
\end{array}$ & $\begin{array}{l}35925 \\
(77,8)\end{array}$ & $\begin{array}{l}33424 \\
(72,7) \\
\end{array}$ & $\begin{array}{l}31295 \\
(68,4) \\
\end{array}$ & $\begin{array}{l}30659 \\
(67,2) \\
\end{array}$ & $\begin{array}{l}30958 \\
(68,1) \\
\end{array}$ & $\begin{array}{l}30819 \\
(67,9)\end{array}$ & $\begin{array}{l}25543 \\
(59,5)\end{array}$ & $\begin{array}{l}23896 \\
(55,9)\end{array}$ & $\begin{array}{l}23292 \\
(54,7)\end{array}$ & $\begin{array}{l}21995 \\
(51,9)\end{array}$ & $\begin{array}{l}21314 \\
(50,5)\end{array}$ \\
\hline $\begin{array}{l}\text { Кількість } \\
\text { випадків } \\
\text { ТБ, в яких } \\
\text { підтверджено } \\
\text { діагноз МРТБ }\end{array}$ & - & - & - & $3329^{* 4}$ & $4056^{\star 4}$ & $4305^{* 4}$ & $\begin{array}{c}8411 \\
(18,5)^{\star 5}\end{array}$ & $\begin{array}{l}9650 \\
(21,3)^{* 5}\end{array}$ & $\begin{array}{l}8432 \\
(19,7)^{\star 5}\end{array}$ & $\begin{array}{l}8440 \\
(19,7)^{\star 5}\end{array}$ & $\begin{array}{l}7778 \\
(18,3)^{\star 5}\end{array}$ & $\begin{array}{l}6757 \\
(15,9)^{\star 5}\end{array}$ & - \\
\hline $\begin{array}{l}\text { ТБ+ВІЛ } \\
\text { (без } \\
\text { рецидивів) }\end{array}$ & $\begin{array}{l}1987 \\
(4,3)\end{array}$ & $\begin{array}{l}2345 \\
(5,0)\end{array}$ & $\begin{array}{l}2902 \\
(6,3)\end{array}$ & $\begin{array}{l}3380 \\
(7,4)\end{array}$ & $\begin{array}{l}3982 \\
(8,7)\end{array}$ & $\begin{array}{l}4157 \\
(9,1)\end{array}$ & $\begin{array}{l}4726 \\
(10,4)\end{array}$ & $\begin{array}{l}4783 \\
(10,5)\end{array}$ & $\begin{array}{l}4441 \\
(10,4)\end{array}$ & - & - & $\begin{array}{l}4458 \\
(10,5)\end{array}$ & $\begin{array}{l}4608 \\
(10,9)\end{array}$ \\
\hline $\begin{array}{l}\text { Нові випадки } \\
+ \text { рецидиви }\end{array}$ & - & - & - & - & - & $\begin{array}{l}4787 \\
(10,5)\end{array}$ & $\begin{array}{l}5531 \\
(12,2)\end{array}$ & $\begin{array}{l}5478 \\
(12,1)\end{array}$ & $\begin{array}{l}5210 \\
(12,1)\end{array}$ & $\begin{array}{l}5572 \\
(13,0)\end{array}$ & $\begin{array}{l}5622 \\
(13,2)\end{array}$ & $\begin{array}{l}5646 \\
(13,3)\end{array}$ & - \\
\hline
\end{tabular}

Примітки тут і в таблицях 2-4: «-» - дані відсутні; *1 - дані використані з фрорми № 4 «3віт про загальну кількість випадків туберкульозу I, II та III категорій хворих (за даними бактеріоскопії і/або культурального дослідження) ТБ 07; *2 - дані використані з форми № 8 «Звіт про захворювання на активний туберкульоз; *3 - у аналітичностатистичних матеріалах із ТБ за 2012, 2013, 2014 та 2018 рр. наведено показники захворюваності на ТБ легень з бактеріовиділенням серед усього населення України в період з 2002 до 2014 р., а також у 2017-2018рр., які були розраховані з урахуванням лише нових випадків захворювання на ТБ легень, разом із тим у матеріалах за 2015, 2016 та 2017 рр. відповідний показник за період з 2011 до 2017 р. розрахований вже з урахуванням як нових випадків, так і рецидивів ТБ легень; *4 - дані використані з фрорми звітності «Звіт про кількість хворих, які були зареєстровані у 4 категорії (ТБ 07 - МРТБ). Показник не включає випадки підозри на МРТБ, яка не була підтверджена протягом звітного року; *5 - дані використані з форми звітності «Звіт про кількість випадків хіміорезистентного туберкульозу, підтверджених та/або за якими розпочато лікування за категоріями 4.1-4.3 протягом звітного кварталу (ТБ 07 - МРТБ). Розрахунок населення за даними фрорми № 20 «Звіт лікувально-профрілактичного закладу» (3О3); *6 - у аналітично-статистичних матеріалах із ТБ за 2012, 2013, 2014 та 2018 рр. наведено показники захворюваності на активний ТБ у поєднанні зі СНІДом серед усього населення України в період 32002 до 2014 р., а також у 2017-2018 рр., які були розраховані з урахуванням лише нових випадків захворювання на активний ТБ, разом із тим у матеріалах за 2015, 2016 та 2017 рр. відповідний показник за період з 2011 до 2017 р. розрахований вже 3 урахуванням як нових випадків, так і рецидивів ТБ; *7 - розрахунок проведений на кількість населення України, включно з тимчасово окупованими Луганською та Донецькою областями.

Луганською і Донецькою областями, притому, що дані стосовно абсолютної кількості випадків ТБ у цих областях були відсутні.

Стосовно областей Причорноморського регіону України, варто зазначити, що тут у період 3 2011 до 2018 р. щороку реєстрували вищі показники захворюваності на ТБ ніж середні по Україні. Найнесприятливішою $є$ епідемічна ситуація в Одеській області, де в період із 2011 до 2018 р. захворюваність на ТБ зросла на 30,3 \%. Незважаючи на певні коливання інтенсивних показників, загалом, у Миколаївській та Херсонській областях за відповідний період відбувся спад захворюваності на ТБ на 30,4 \% та 23,7 \% (рис. 1).

Найнебезпечнішими 3 точки зору розповсюдження ТБ-інфекції $€$ Хворі на ТБ легень з масивним бактеріовиділенням, тобто тоді, коли МБТ виявляють при звичайній мікроскопії мокротиння. Разом із тим, деякі фрахівці вважають, що небезпека зараження від хворого на ТБ різко зменшується, якщо він протягом щонайменше 2-х тижнів отримує інтенсивну протитуберкульозну терапію [9].

У цілому по Україні з 2011 до 2017 р. спостерігали незначні коливання інтенсивного показника захворюваності на ТБ легень з бактеріовиділенням (рис. 2).

В усіх областях Причорноморського регіону цей показник, знову ж таки, щороку перевищував середній по Україні. Досить інтенсивний темп приросту захворюваності на ТБ із бактеріовиділенням спостерігали в Одеській області в період 32011 до 2016 р. - в середньому + 10,2 \% 
Таблиця 2. Захворюваність на всі форми активного туберкульозу, туберкульоз легень 3 бактеріовиділенням, мультирезистентний туберкульоз та туберкульоз у поєднанні зі СНІДом в Одеській області в період з 2006 до 2018 р. (абс., на 100 тис. населення)

\begin{tabular}{|c|c|c|c|c|c|c|c|c|c|c|c|c|c|}
\hline \multirow{2}{*}{ Показник } & \multicolumn{13}{|c|}{ Роки } \\
\hline & 2006 & 2007 & 2008 & 2009 & 2010 & 2011 & 2012 & 2013 & 2014 & 2015 & 2016 & 2017 & 2018 \\
\hline $\begin{array}{l}\text { Захворюваність } \\
\text { (ВДТБ+РТБ) }\end{array}$ & - & - & - & - & $\begin{array}{l}2049^{* 1} \\
(86,1)\end{array}$ & $\begin{array}{c}2329^{* 2} \\
(98,0)\end{array}$ & $\begin{array}{l}2419^{\star 2} \\
(101,8)\end{array}$ & \begin{tabular}{|l|}
$2410^{* 2}$ \\
$(101,1)$
\end{tabular} & \begin{tabular}{|c|}
$2701^{\star 2}$ \\
$(113,2)$
\end{tabular} & \begin{tabular}{|l|}
$2952^{* 2}$ \\
$(123,8)$
\end{tabular} & \begin{tabular}{|l|}
$3108^{* 2}$ \\
$(130,6)$
\end{tabular} & $\begin{array}{l}3039^{* 2} \\
(127,9)\end{array}$ & $\begin{array}{l}3335^{\star 2} \\
(140,6)\end{array}$ \\
\hline $\begin{array}{l}\text { ТБ легень } 3 \\
\text { бактеріовиділенням } \\
\text { (без рецидивів) }^{\star 2,3}\end{array}$ & 36,4 & 34,1 & 36,9 & 33,7 & 33,6 & 40,2 & 43,7 & 53,1 & 54,4 & - & - & $\begin{array}{c}1242 \\
(52,3)\end{array}$ & $\begin{array}{c}1301 \\
(54,8)\end{array}$ \\
\hline $\begin{array}{l}\text { Нові випадки + } \\
\text { рецидиви } 2,3\end{array}$ & - & - & - & - & - & $\begin{array}{c}1081 \\
(45,5)\end{array}$ & $\begin{array}{l}1218 \\
(51,2)\end{array}$ & $\begin{array}{l}1499 \\
(62,9)\end{array}$ & $\begin{array}{l}1607 \\
(67,4)\end{array}$ & $\begin{array}{l}1806 \\
(75,7)\end{array}$ & $\begin{array}{l}1869 \\
(78,6)\end{array}$ & $\begin{array}{c}1502 \\
(63,2)\end{array}$ & - \\
\hline ВДТБ & -- & $\begin{array}{l}2077 \\
(87,1)\end{array}$ & $\begin{array}{l}2084 \\
(87,4)\end{array}$ & $\begin{array}{c}1873 \\
(78,7)\end{array}$ & $\begin{array}{l}1842 \\
(77,4)\end{array}$ & $\begin{array}{l}2087 \\
(87,8) \\
\end{array}$ & $\begin{array}{l}2235 \\
(94,0)\end{array}$ & $\begin{array}{l}2162 \\
(90,7)\end{array}$ & $\begin{array}{l}2342 \\
(98,2)\end{array}$ & \begin{tabular}{|c|}
2446 \\
$(102,5)$
\end{tabular} & \begin{tabular}{|c|}
2594 \\
$(109,0)$
\end{tabular} & $\begin{array}{c}2561 \\
(107,8)\end{array}$ & $\begin{array}{c}2732 \\
(115,2)\end{array}$ \\
\hline $\begin{array}{l}\text { Кількість випадків } \\
\text { ТБ, в яких } \\
\text { підтверджено } \\
\text { діагноз МРТБ }\end{array}$ & - & - & - & $127^{* 4}$ & $263^{* 4}$ & $245^{* 4}$ & $\begin{array}{c}620 \\
(26,1)^{\star 5}\end{array}$ & $\begin{array}{c}739 \\
(31,0)^{* 5}\end{array}$ & $\begin{array}{c}779 \\
(32,7)^{\star 5}\end{array}$ & $\begin{array}{c}780 \\
(32,7)^{\star 5}\end{array}$ & $\begin{array}{c}716 \\
(30,1)^{\star 5}\end{array}$ & $\begin{array}{c}588 \\
(24,8)^{\star 5}\end{array}$ & - \\
\hline 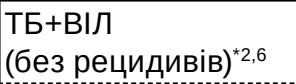 & $\begin{array}{c}278 \\
(11,6)\end{array}$ & $\begin{array}{c}256 \\
(10,7)\end{array}$ & $\begin{array}{c}303 \\
(12,7)\end{array}$ & $\begin{array}{c}330 \\
(13,9)\end{array}$ & $\begin{array}{c}373 \\
(15,7)\end{array}$ & $\begin{array}{c}475 \\
(20,0)\end{array}$ & $\begin{array}{c}556 \\
(23,4)\end{array}$ & $\begin{array}{c}588 \\
(24,7)\end{array}$ & $\begin{array}{c}735 \\
(30,8)\end{array}$ & - & - & $\begin{array}{c}1066 \\
(44,9)\end{array}$ & $\begin{array}{c}1247 \\
(52,6)\end{array}$ \\
\hline $\begin{array}{l}\text { Нові випадки + } \\
\text { рецидиви } 2,6\end{array}$ & - & - & - & - & - & $\begin{array}{c}529 \\
(22,2)\end{array}$ & $\begin{array}{c}591 \\
(24,9)\end{array}$ & $\begin{array}{c}657 \\
(27,6)\end{array}$ & $\begin{array}{c}839 \\
(35,2)\end{array}$ & $\begin{array}{l}1045 \\
(43,8)\end{array}$ & $\begin{array}{l}1139 \\
(47,9)\end{array}$ & $\begin{array}{c}1270 \\
(53,5)\end{array}$ & - \\
\hline
\end{tabular}

Таблиця 3. Захворюваність на всі форми активного туберкульозу, туберкульоз легень 3 бактеріовиділенням, мультирезистентний туберкульоз та туберкульоз у поєднанні зі СНІДом у Миколаївській області в період з 2006 до 2018 р. (абс., на 100 тис. населення)

\begin{tabular}{|c|c|c|c|c|c|c|c|c|c|c|c|c|c|}
\hline \multirow{2}{*}{ Показник } & \multicolumn{13}{|c|}{ Роки } \\
\hline & 2006 & 2007 & 2008 & 2009 & 2010 & 2011 & 2012 & 2013 & 2014 & 2015 & 2016 & 2017 & 2018 \\
\hline $\begin{array}{l}\text { Захворюваність } \\
\text { (ВДТБ+РТБ) }\end{array}$ & - & - & - & - & $\begin{array}{l}1100^{* 1} \\
(92,5)\end{array}$ & $\begin{array}{l}1178^{* 2} \\
(99,6)\end{array}$ & $\begin{array}{l}1141^{* 2} \\
(96,9)\end{array}$ & \begin{tabular}{|c|}
$989^{* 2}$ \\
$(84,3)$
\end{tabular} & \begin{tabular}{|c|}
$955^{* 2}$ \\
$(81,8)$
\end{tabular} & $\begin{array}{l}1002^{* 2} \\
(86,1)\end{array}$ & \begin{tabular}{|c|}
$950^{* 2}$ \\
$(82,1)$
\end{tabular} & $\begin{array}{l}857^{* 2} \\
(74,6)\end{array}$ & $\begin{array}{l}791^{* 2} \\
(69,3)\end{array}$ \\
\hline $\begin{array}{l}\text { ТБ легень } 3 \\
\text { бактеріовиділенням } \\
\text { (без рецидивів) }^{\star 2,3}\end{array}$ & 39,3 & 41,0 & 39,4 & 41,1 & 29,7 & 37,5 & 34,6 & 42,9 & 41,9 & - & - & $\begin{array}{c}428 \\
(37,2)\end{array}$ & $\begin{array}{c}434 \\
(38,0)\end{array}$ \\
\hline $\begin{array}{l}\text { Нові випадки + } \\
\text { рецидиви }{ }^{\star 2,3}\end{array}$ & - & - & - & - & - & $\begin{array}{c}510 \\
(43,1)\end{array}$ & $\begin{array}{c}475 \\
(40,3)\end{array}$ & $\begin{array}{c}583 \\
(49,7)\end{array}$ & $\begin{array}{c}591 \\
(50,6)\end{array}$ & $\begin{array}{c}615 \\
(52,9)\end{array}$ & $\begin{array}{c}594 \\
(51,3)\end{array}$ & $\begin{array}{c}564 \\
(49,1)\end{array}$ & - \\
\hline ВДТБ & -- & $\begin{array}{c}1262 \\
(104,2)\end{array}$ & $\begin{array}{c}1226 \\
(101,9)\end{array}$ & $\begin{array}{l}1167 \\
(97,6)\end{array}$ & \begin{tabular}{|c|}
1076 \\
$(90,5)$
\end{tabular} & $\begin{array}{c}1056 \\
(89,3)\end{array}$ & $\begin{array}{l}1028 \\
(87,3)\end{array}$ & $\begin{array}{c}908 \\
(77,4)\end{array}$ & $\begin{array}{c}838 \\
(71,8)\end{array}$ & \begin{tabular}{|c|}
803 \\
$(69,0)$
\end{tabular} & \begin{tabular}{|c|}
777 \\
$(67,1)$
\end{tabular} & \begin{tabular}{|c|}
686 \\
$(59,7)$
\end{tabular} & $\begin{array}{c}656 \\
(57,5)\end{array}$ \\
\hline $\begin{array}{l}\text { Кількість випадків } \\
\text { ТБ, в яких } \\
\text { підтверджено } \\
\text { діагноз МРТБ }\end{array}$ & - & - & - & $30^{* 4}$ & $60^{* 4}$ & $72^{* 4}$ & $\begin{array}{c}159 \\
(13,5)^{\star 5}\end{array}$ & $\begin{array}{c}473 \\
(40,3)^{\star 5}\end{array}$ & $\begin{array}{c}360 \\
(30,8)^{* 5}\end{array}$ & $\begin{array}{c}462 \\
(39,7)^{\star 5}\end{array}$ & $\begin{array}{c}475 \\
(41,0)^{\star 5}\end{array}$ & $\begin{array}{c}337 \\
(29,3)^{\star 5}\end{array}$ & - \\
\hline $\begin{array}{l}\text { ТБ+ВІЛ } \\
(\text { без рецидивів) }\end{array}$ & $\begin{array}{l}1841 \\
(15,1) \\
\end{array}$ & $\begin{array}{c}255 \\
(21,1)\end{array}$ & $\begin{array}{c}335 \\
(27,9) \\
\end{array}$ & $\begin{array}{c}280 \\
(23,4)\end{array}$ & $\begin{array}{c}275 \\
(23,1) \\
\end{array}$ & $\begin{array}{c}253 \\
(21,4)\end{array}$ & $\begin{array}{c}240 \\
(20,4) \\
\end{array}$ & \begin{tabular}{c|}
228 \\
$(19,4)$ \\
\end{tabular} & $\begin{array}{c}231 \\
(19,8) \\
\end{array}$ & - & - & $\begin{array}{c}161 \\
(14,0)\end{array}$ & $\begin{array}{c}164 \\
(14,4)\end{array}$ \\
\hline $\begin{array}{l}\text { Нові випадки + } \\
\text { рецидиви }{ }^{\star 2,6}\end{array}$ & - & - & - & - & - & $\begin{array}{c}286 \\
(24,2)\end{array}$ & $\begin{array}{c}262 \\
(22,3)\end{array}$ & $\begin{array}{c}250 \\
(21,3)\end{array}$ & $\begin{array}{c}269 \\
(23,0)\end{array}$ & $\begin{array}{c}268 \\
(23,0)\end{array}$ & $\begin{array}{c}279 \\
(24,1)\end{array}$ & $\begin{array}{c}215 \\
(18,7)\end{array}$ & - \\
\hline
\end{tabular}

щороку, при цьому відносно різке його зниження (на 19,6 \% порівняно з 2016 р.) зафріксовано в 2017 р. Дещо схожі коливання інтенсивного показника захворюваності на ТБ легень з бактеріовиділенням спостерігали і в Херсонській області. У Миколаївській області після підвищення на 18,9 \% в 2013 р., порівняно з попереднім, цей показник залишався відносно стабільним до 2017 р.

Аналізуючи динаміку зміни інтенсивних показників захворюваності на нові випадки ТБ, можна стверджувати, що як в Україні в цілому, так і в Миколаївській та Херсонській областях в період з 2007 до 2018 р. відбувалося поступове зниження захворюваності на ВДТБ. Причому найдраматичніше зниження захворюваності за даний період спостерігали в Херсонській області - на 56,9 \%. Протилежну тенденцію було зафіксовано в Одеській області - тут у 2018 р. захворюваність на нові випадки ТБ зросла на 24,4% порівняно 3 показником 2007 р. (рис. 3).

Варто відзначити, що в усіх областях Причорноморського регіону протягом всіх років спостереження показник захворюваності на ВДТБ був вищим за середній по Україні. 
Таблиця 4. Захворюваність на всі форми активного туберкульозу, туберкульоз легень 3 бактеріовиділенням, мультирезистентний туберкульоз та туберкульоз у поєднанні зі СНІДом у Херсонській області в період з 2006 до 2018 р. (абс., на 100 тис. населення)

\begin{tabular}{|c|c|c|c|c|c|c|c|c|c|c|c|c|c|}
\hline \multirow{2}{*}{ Показник } & \multicolumn{13}{|c|}{ Роки } \\
\hline & 2006 & 2007 & 2008 & 2009 & 2010 & 2011 & 2012 & 2013 & 2014 & 2015 & 2016 & 2017 & 2018 \\
\hline $\begin{array}{l}\text { Захворюваність } \\
\text { (ВДТБ+РТБ) }\end{array}$ & - & - & - & - & $\begin{array}{l}1249^{* 1} \\
(114,4)\end{array}$ & $\begin{array}{l}1189^{* 2} \\
(109,4)\end{array}$ & $\begin{array}{l}1239^{* 2} \\
(114,5)\end{array}$ & $\begin{array}{c}1158^{* 2} \\
(107,5)\end{array}$ & $\begin{array}{l}1090^{* 2} \\
(101,8)\end{array}$ & $\begin{array}{l}1132^{* 2} \\
(106,1)\end{array}$ & $\begin{array}{l}1051^{* 2} \\
(99,1)\end{array}$ & $\begin{array}{l}979^{* 2} \\
(92,9)\end{array}$ & $\begin{array}{l}872^{* 2} \\
(83,4)\end{array}$ \\
\hline $\begin{array}{l}\text { ТБ легень } 3 \\
\text { бактеріовиділенням } \\
\text { (без рецидивів) }^{* 2,3}\end{array}$ & 44,7 & 50,6 & 44,8 & 44,4 & 42,2 & 41,9 & 43,2 & 44,3 & 45,4 & - & - & $\begin{array}{c}505 \\
(47,9)\end{array}$ & $\begin{array}{c}456 \\
(43,6)\end{array}$ \\
\hline $\begin{array}{l}\text { Нові випадки + } \\
\text { рецидиви }{ }^{2,3}\end{array}$ & - & - & - & - & - & $\begin{array}{c}517 \\
(47,6)\end{array}$ & $\begin{array}{c}516 \\
(47,7)\end{array}$ & $\begin{array}{c}586 \\
(54,4)\end{array}$ & $\begin{array}{c}636 \\
(59,4)\end{array}$ & $\begin{array}{c}738 \\
(69,2)\end{array}$ & $\begin{array}{c}723 \\
(68,1)\end{array}$ & $\begin{array}{c}663 \\
(62,9)\end{array}$ & - \\
\hline ВДТБ & - & $\begin{array}{c}1689 \\
(151,4)\end{array}$ & $\begin{array}{c}1369 \\
(123,8)\end{array}$ & $\begin{array}{c}1209 \\
(110,1)\end{array}$ & $\begin{array}{c}1167 \\
(106,9)\end{array}$ & $\begin{array}{c}1070 \\
(98,5)\end{array}$ & $\begin{array}{c}1167 \\
(107,9)\end{array}$ & $\begin{array}{l}1036 \\
(96,2)\end{array}$ & $\begin{array}{c}904 \\
(84,4)\end{array}$ & \begin{tabular}{|c|}
875 \\
$(82,0)$
\end{tabular} & $\begin{array}{c}799 \\
(75,3)\end{array}$ & $\begin{array}{c}770 \\
(73,0)\end{array}$ & $\begin{array}{c}683 \\
(65,3)\end{array}$ \\
\hline $\begin{array}{l}\text { Кількість випадків } \\
\text { ТБ, в яких } \\
\text { підтверджено } \\
\text { діагноз МРТБ }\end{array}$ & - & - & -- & $77^{* 4}$ & $160^{* 4}$ & $180^{* 4}$ & $\begin{array}{c}404 \\
(37,3)^{\star 5}\end{array}$ & $\begin{array}{c}372 \\
(34,5)^{* 5}\end{array}$ & $\begin{array}{c}348 \\
(32,5)^{\star 5}\end{array}$ & $\begin{array}{c}333 \\
(31,2)^{\star 5}\end{array}$ & $\begin{array}{c}324 \\
(30,5)^{* 5}\end{array}$ & $\begin{array}{c}271 \\
(25,7)^{\star 5}\end{array}$ & - \\
\hline $\begin{array}{l}\text { ТБ+ВІЛ } \\
\text { (без рецидивів) }{ }^{\star 2,6}\end{array}$ & $\begin{array}{c}86 \\
(7,6)\end{array}$ & $\begin{array}{c}79 \\
(7,1)\end{array}$ & $\begin{array}{c}80 \\
(7,2)\end{array}$ & $\begin{array}{c}85 \\
(7,7)\end{array}$ & $\begin{array}{c}125 \\
(11,4)\end{array}$ & $\begin{array}{c}135 \\
(12,4)\end{array}$ & $\begin{array}{c}153 \\
(14,1)\end{array}$ & $\begin{array}{c}130 \\
(12,1)\end{array}$ & $\begin{array}{c}156 \\
(14,6)\end{array}$ & - & - & $\begin{array}{c}136 \\
(12,9)\end{array}$ & $\begin{array}{c}124 \\
(11,9)\end{array}$ \\
\hline $\begin{array}{l}\text { Нові випадки + } \\
\text { рецидиви } 2,6\end{array}$ & - & - & - & - & - & $\begin{array}{c}147 \\
(13,5)\end{array}$ & $\begin{array}{c}162 \\
(15,0)\end{array}$ & $\begin{array}{c}142 \\
(13,2) \\
\end{array}$ & $\begin{array}{c}183 \\
(17,1)\end{array}$ & $\begin{array}{c}201 \\
(18,8) \\
\end{array}$ & $\begin{array}{c}208 \\
(19,6) \\
\end{array}$ & $\begin{array}{c}202 \\
(19,2) \\
\end{array}$ & - \\
\hline
\end{tabular}

Захворюваність на ТБ (ВДТБ+РТБ), на 100 тис. населення

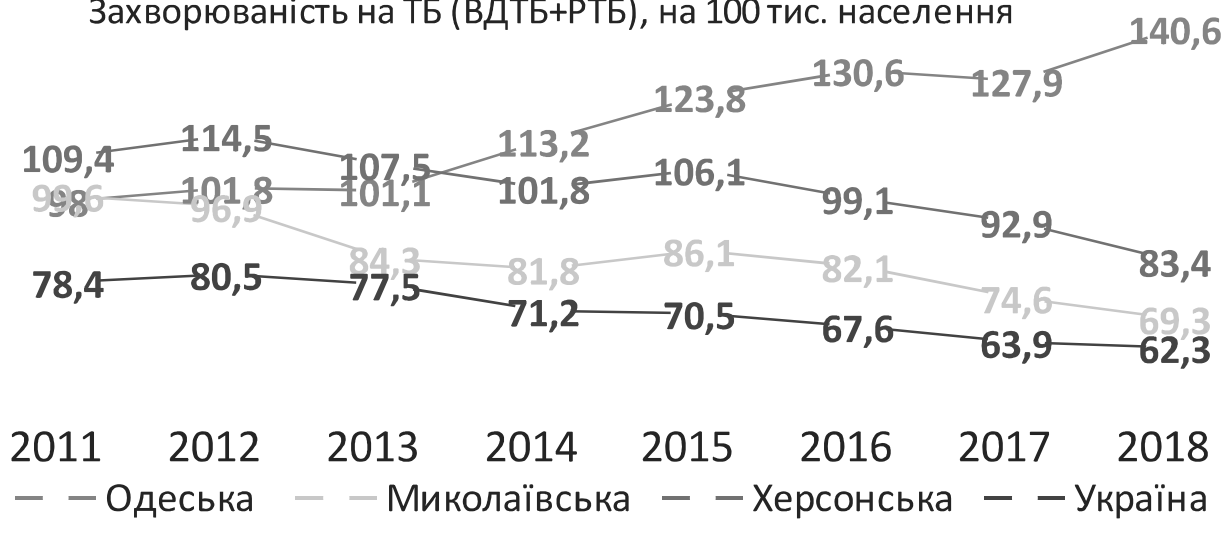

Puc. 1. Захворюваність на туберкульоз (нові випадки + рецидиви) у Причорноморському регіоні України в період з 2011 до 2018 р.

ТБ легень з бактеріовиділенням (нові випадки + рецидиви), на 100 тис. населення

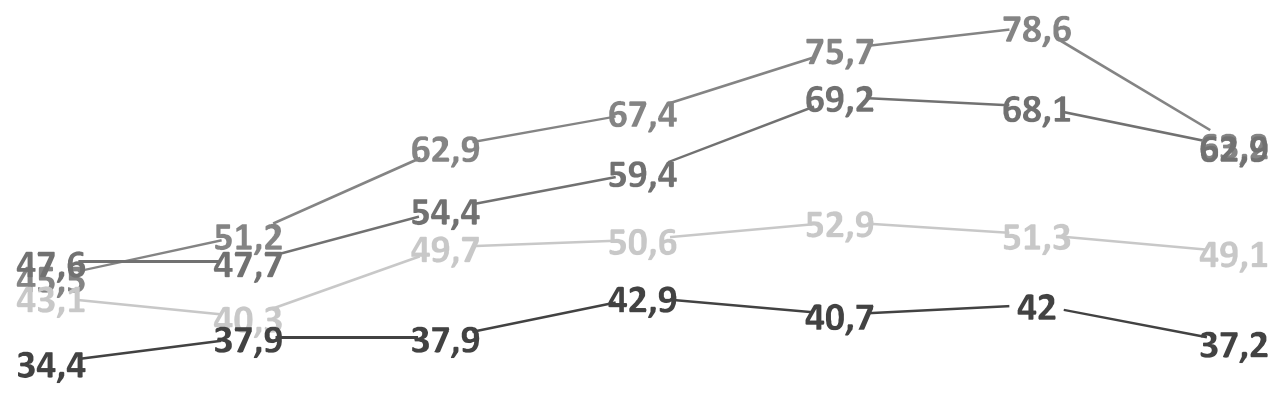
20112012
20132014
2015
2016
2017
- - Одеська
Миколаївська
- Херсонська
- - Україна

Puc. 2. Захворюваність на туберкульоз легень з бактеріовиділенням (нові випадки + рецидиви) у Причорноморському регіоні України в період з 2011 до 2017 р. 
Як вже згадували, Україна є однією з 30 країн світу, які визнано країнами з високим тягарем МРТБ, а в 2014 р. Україна вперше потрапила до п'ятірки країн із найвищим тягарем МРТБ. Поширеність ТБ із множинною лікарською стійкістю, як правило, є наслідком недоліків діючої системи охорони здоров'я, а саме відсутності зв'язків між різними секторами системи, неналагодженої інфраструктури для діагностики та лікування ТБ та зокрема МРТБ, проблем доступу до протитуберкульозних хіміопрепаратів тощо [5].

Серед регіонів України найвищими показниками захворюваності на МРТБ у 2017 р. відрізнялися Миколаївська, Херсонська, Дніпропетровська та Одеська області, тобто на частку Причорноморського регіону припадала найбільша кількість випадків вперше встановленого МРТБ - $17 \%$ від загальної кількості в Україні (рис. 4).

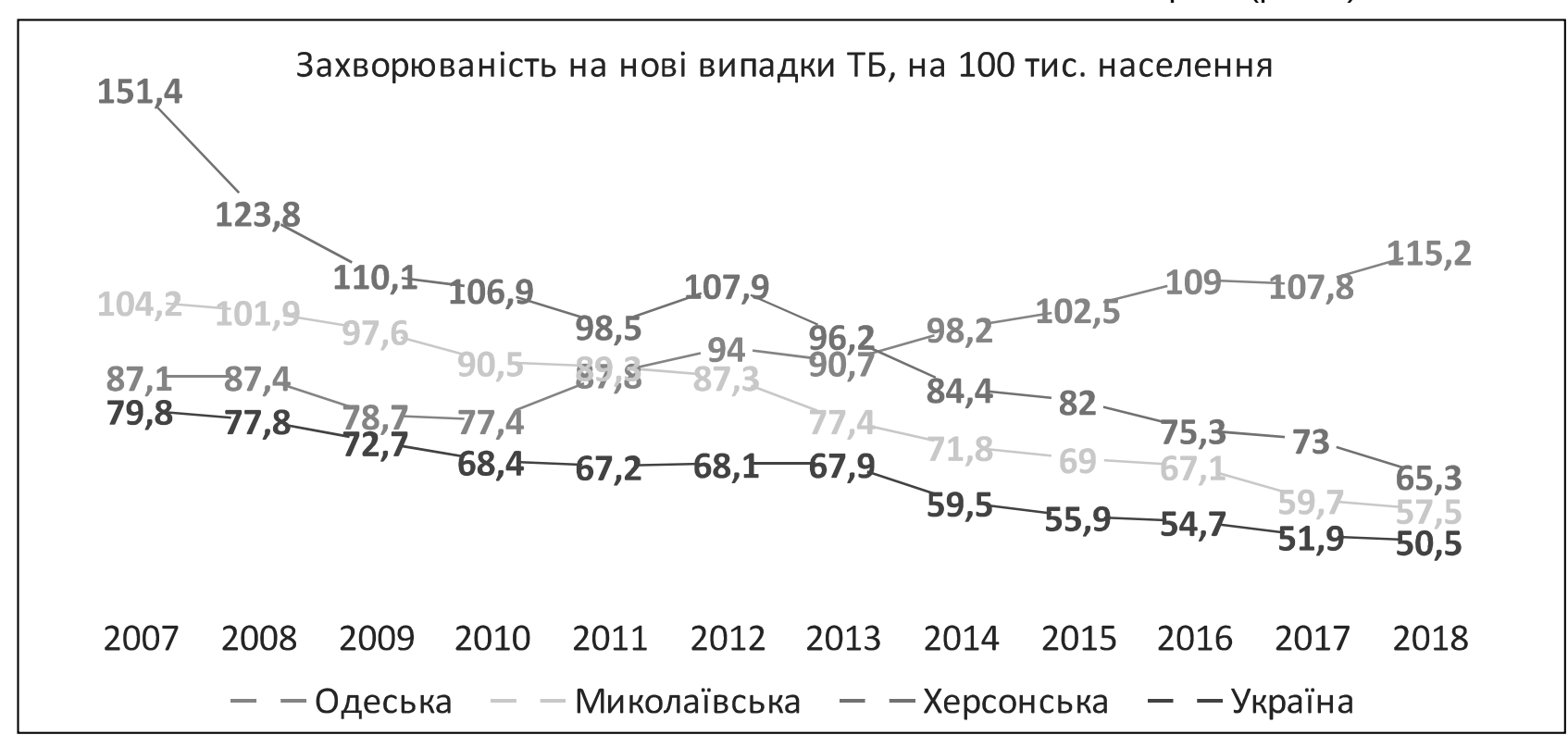

Рuc. 3. Захворюваність на нові випадки туберкульозу в Причорноморському регіоні України в період з 2007 до 2018 р.

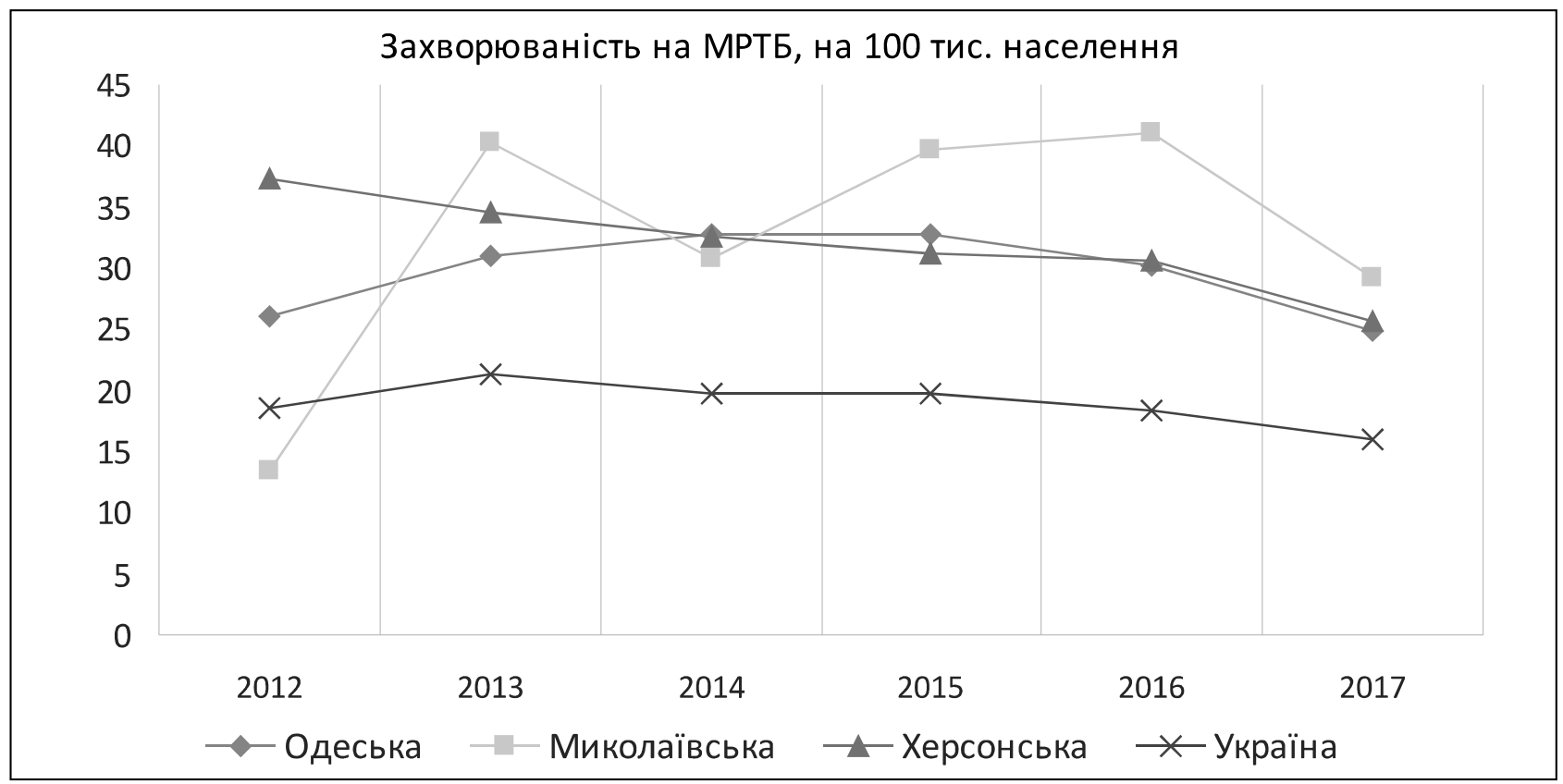

Puc. 4. Захворюваність на мультирезистентний туберкульоз у Причорноморському регіоні України в період з 2012 до 2017 р.

Привертають увагу й значні коливання показників захворюваності на МРТБ у Миколаївській області, що, можливо, є наслідком низького рівня виявлення мультирезистентного туберкульозу. На окрему увагу заслуговує той факт, що на низький рівень виявлення випадків МРТБ в Україні в 2015 р. вказувало Європейське бюро ВООЗ. 
Інтенсивний показник захворюваності на коінфрекцію ВІЛ/ТБ в Україні збільшився на 21 \% в період 32011 до 2017 р. Найстрімкіші темпи зростання захворюваності були зареєстровані в Одеській області, де щорічний середній темп приросту становить $13,5 \%$, а загалом захворюваність на ВІЛ/ТБ у 2017 р. зросла на 58,5 \% порівняно 32011 р. Значно менші темпи приросту, а подекуди й спади захворюваності спостерігали протягом відповідного періоду в Миколаївській та Херсонській областях. В усіх областях Причорноморського регіону захворюваність на ВІЛ/ТБ щороку виявляли більшою за середній показник по Україні (рис. 5).

\section{Захворюваність на ТБ+ВІЛ (нові випадки + рецидиви),} на 100 тис. населення

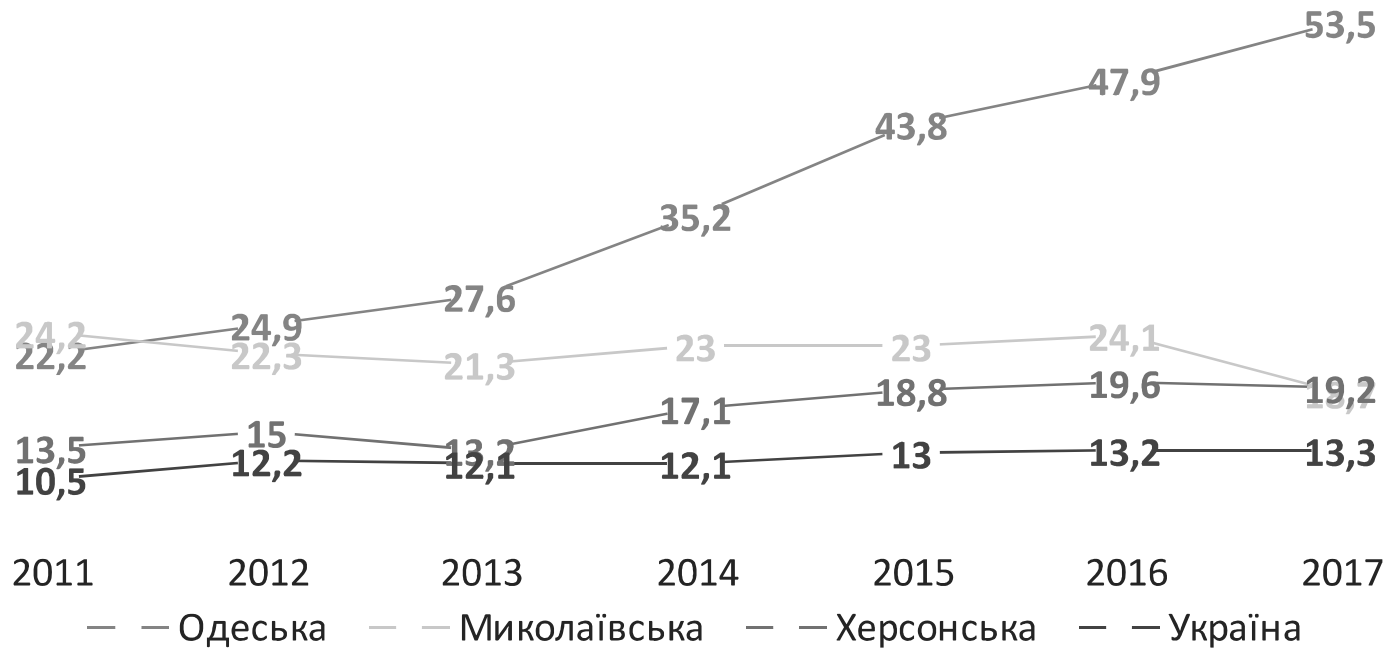

Рис. 5. Захворюваність на ко-інфекцію ТБ/ВІЛ у Причорноморському регіоні України в період з 2011 до 2017 р.

У 2018 р. відсоток нових випадків ко-інфекції ТБ/ВІЛ у Причорноморському регіоні склав 33 \% від загальної кількості по Україні, причому з них 27 \% припадало на Одеську область (рис. 6).

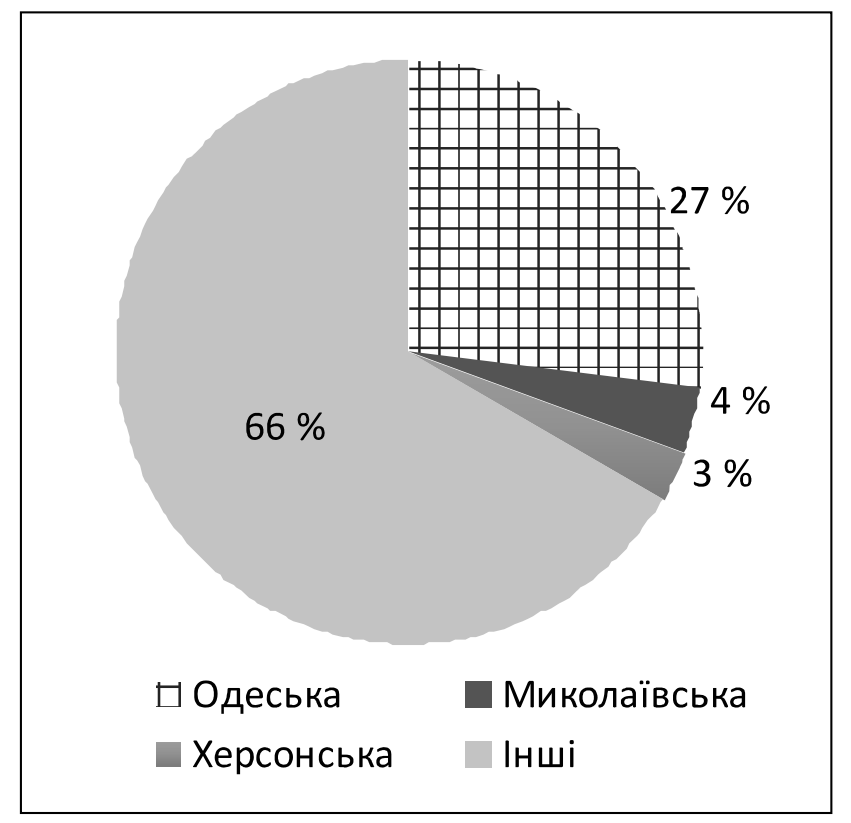

Puc. 6. Структура захворюваності на активний туберкульоз у поєднанні з ВІЛ (без рецидивів) у Причорноморському регіоні, 2018 р.
32006 до 2017 р. інтенсивний показник поширеності активного ТБ в Україні скорочувався в середньому на 8,7 \% за рік (рис. 7).

В областях Причорноморського регіону також простежується загальна тенденція до зниження поширеності активного ТБ серед населення. У даному випадку найяскравішим прикладом $€$ Херсонська область, де з 2006 до 2017 р. поширеність ТБ щороку знижувалася в середньому на 10,5 \% (табл. 5). Варто відзначити зростання поширеності ТБ в Одеській області з 2015 р. Загалом в Одеській, Миколаївській та Херсонській областях реєструють найвищі рівні поширеності ТБ серед усіх регіонів України.

Відображенням критичної епідемічної ситуації з ВІЛ-інфекції в Україні та, особливо, у Причорноморському регіоні, $€$ високі, порівняно 3 середньоєвропейськими, показники поширення ТБ у поєднанні з ВІЛ (рис. 8.)

32012 до 2017 р. в цілому по Україні спостерігають зниження рівня летальності від ТБ (без урахування випадків ко-інфекції ТБ/ВІЛ) з середнім річним темпом зниження 10,1 \% [5]. У цілому, аналогічну тенденцію простежують і в областях Причорноморського регіону, тут, починаючи 3 2016 р., приріст летальності від ТБ реєструють лише в Одеській області (рис. 9). 
Поширеність усіх форм активного ТБ, на 100 тис. населення

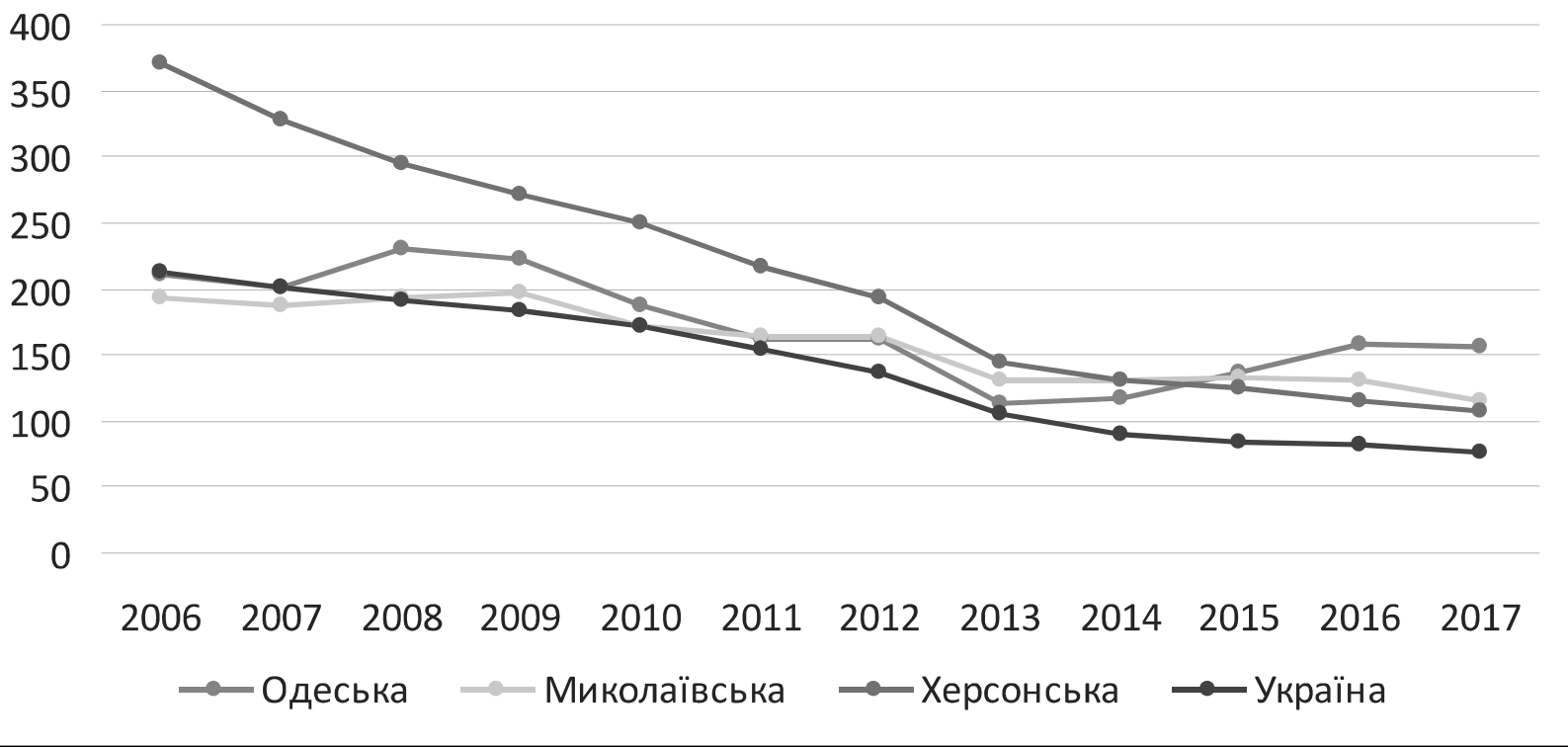

Puc. 7. Поширеність усіх форм активного туберкульозу в Причорноморському регіоні України в період 32006 до 2017 р.

Таблиця 5. Поширеність всіх форм активного туберкульозу та всіх форм активного туберкульозу в поєднанні з хворобою, зумовленою ВІЛ (ТБ/ВІЛ) в областях Причорноморського регіону України в період з 2006 до 2018 р.

\begin{tabular}{|c|c|c|c|c|c|c|c|c|}
\hline \multirow{2}{*}{ Рік } & \multicolumn{6}{|c|}{ Поширеність по регіонах (абс., на 100 тис. населення) } \\
\cline { 2 - 9 } & \multicolumn{2}{|c|}{ Одеська } & \multicolumn{2}{|c|}{ Миколаївська } & \multicolumn{2}{c|}{ Херсонська } & \multicolumn{2}{c|}{ Україна } \\
\cline { 2 - 9 } & ТБ & ТБ+ВІЛ & ТБ & ТБ+ВІЛ & ТБ & ТБ+ВІЛ & ТБ & ТБ+ВІЛ \\
\hline 2006 & 5009 & 489 & 2360 & 320 & 4172 & 119 & 99346 & 3884 \\
& $(210,0)$ & $(20,5)$ & $(194,0)$ & $(26,3)$ & $(371,6)$ & $(10,6)$ & $(212,3)$ & $(8,3)$ \\
\hline 2007 & 4809 & 472 & 2264 & 408 & 3655 & 132 & 93195 & 4588 \\
& $(201,7)$ & $(19,8)$ & $(186,9)$ & $(33,7)$ & $(327,6)$ & $(11,8)$ & $(200,6)$ & $(9,9)$ \\
\hline 2008 & 5472 & 538 & 2330 & 510 & 3249 & 164 & 88758 & 5531 \\
& $(229,6)$ & $(22,6)$ & $(193,7)$ & $(42,4)$ & $(293,7)$ & $(14,8)$ & $(192,1)$ & $(12,0)$ \\
\hline 2009 & 5302 & 598 & 2351 & 450 & 2987 & 180 & 83990 & 6041 \\
& $(222,7)$ & $(25,1)$ & $(196,7)$ & $(37,7)$ & $(272,1)$ & $(16,4)$ & $(182,7)$ & $(13,1)$ \\
\hline 2010 & 4444 & 640 & 2048 & 407 & 2734 & 208 & 78635 & 6903 \\
& $(186,7)$ & $(26,9)$ & $(172,3)$ & $(34,2)$ & $(250,4)$ & $(19,0)$ & $(171,8)$ & $(15,1)$ \\
\hline 2011 & 3836 & 683 & 1933 & 391 & 2354 & 219 & 70725 & 7196 \\
& $(161,3)$ & $(28,7)$ & $(163,5)$ & $(33,1)$ & $(216,6)$ & $(20,2)$ & $(155,1)$ & $(15,8)$ \\
\hline 2012 & 3867 & 727 & 1926 & 406 & 2099 & 240 & 61749 & 7456 \\
& $(162,7)$ & $(30,6)$ & $(163,6)$ & $(34,5)$ & $(194,0)$ & $(22,2)$ & $(135,9)$ & $(16,4)$ \\
\hline 2013 & 2513 & 685 & 1427 & 363 & 1425 & 216 & 43376 & 6599 \\
& $(113,2)$ & $(28,7)$ & $(130,1)$ & $(31,0)$ & $(143,6)$ & $(20,1)$ & $(104,9)$ & $(14,5)$ \\
\hline 2014 & 2648 & 770 & 1442 & 356 & 1307 & 236 & 35733 & 6216 \\
& $(117,7)$ & $(32,3)$ & $(130,0)$ & $(30,5)$ & $(131,2)$ & $(22,0)$ & $(90,2)$ & $(14,5)$ \\
\hline 2015 & 3262 & 929 & 1540 & 360 & 1323 & 217 & 36228 & 6185 \\
& $(136,7)$ & $(38,9)$ & $(132,3)$ & $(30,9)$ & $(124,1)$ & $(20,3)$ & $(84,7)$ & $(14,5)$ \\
\hline 2016 & 3747 & 1151 & 1508 & 380 & 1220 & 188 & 34966 & 6386 \\
& $(157,5)$ & $(48,4)$ & $(130,3)$ & $(32,8)$ & $(115,0)$ & $(17,7)$ & $(82,1)$ & $(15,0)$ \\
\hline 2017 & 3708 & 1394 & 1322 & 333 & 1131 & 194 & 32492 & 6594 \\
& $(156,1)$ & $(58,7)$ & $(115,0)$ & $(29,0)$ & $(107,3)$ & $(18,4)$ & $(76,6)$ & $(15,5)$ \\
\hline 2018 & - & - & - & - & - & - & - & - \\
\hline
\end{tabular}

Примітки. «-» - дані відсутні; ${ }^{*}$ - дані використані з фрорми № 33-здоров «Звіт про хворих на туберкульоз». 
Поширеність ТБ+ВІЛ, на 100 тис. населення

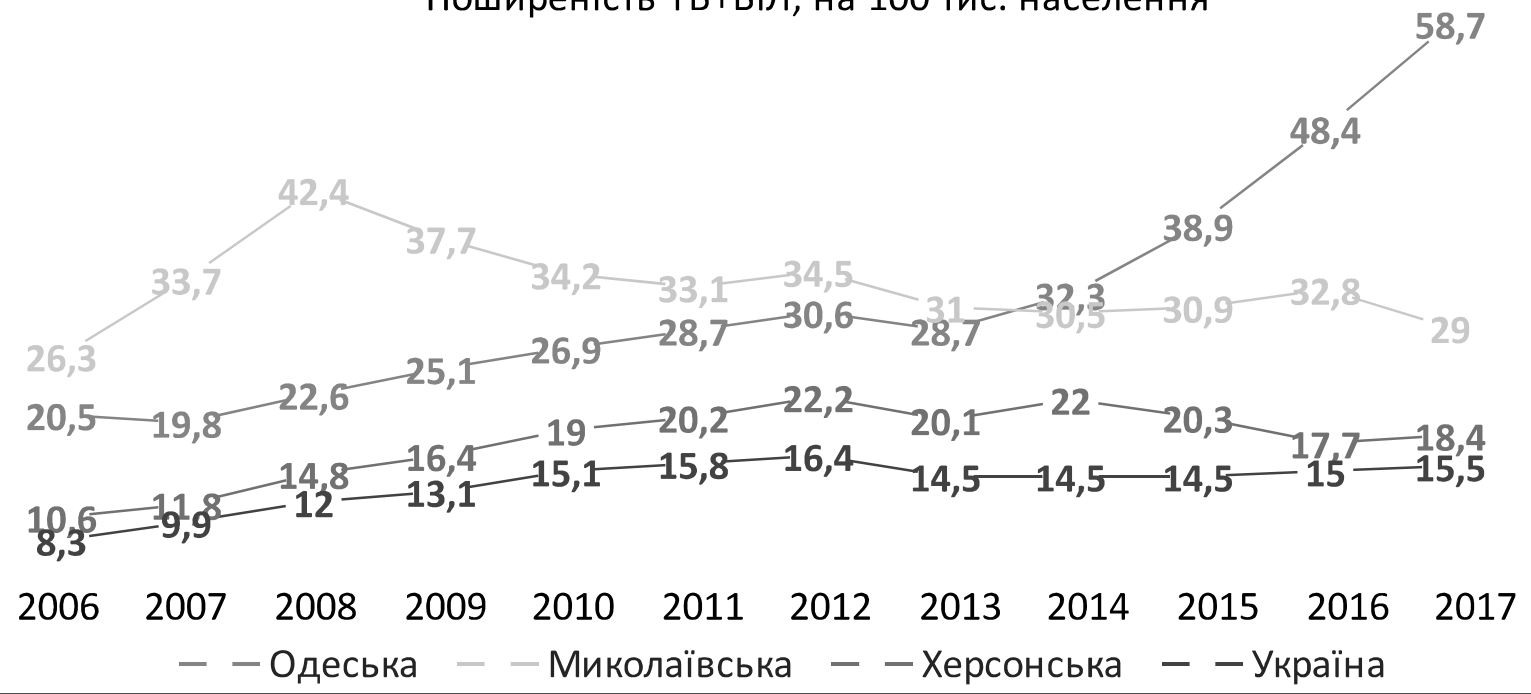

Рис. 8. Поширеність випадків ко-інфекції ТБ/ВІЛ у Причорноморському регіоні України в період 32006 до 2017 p.

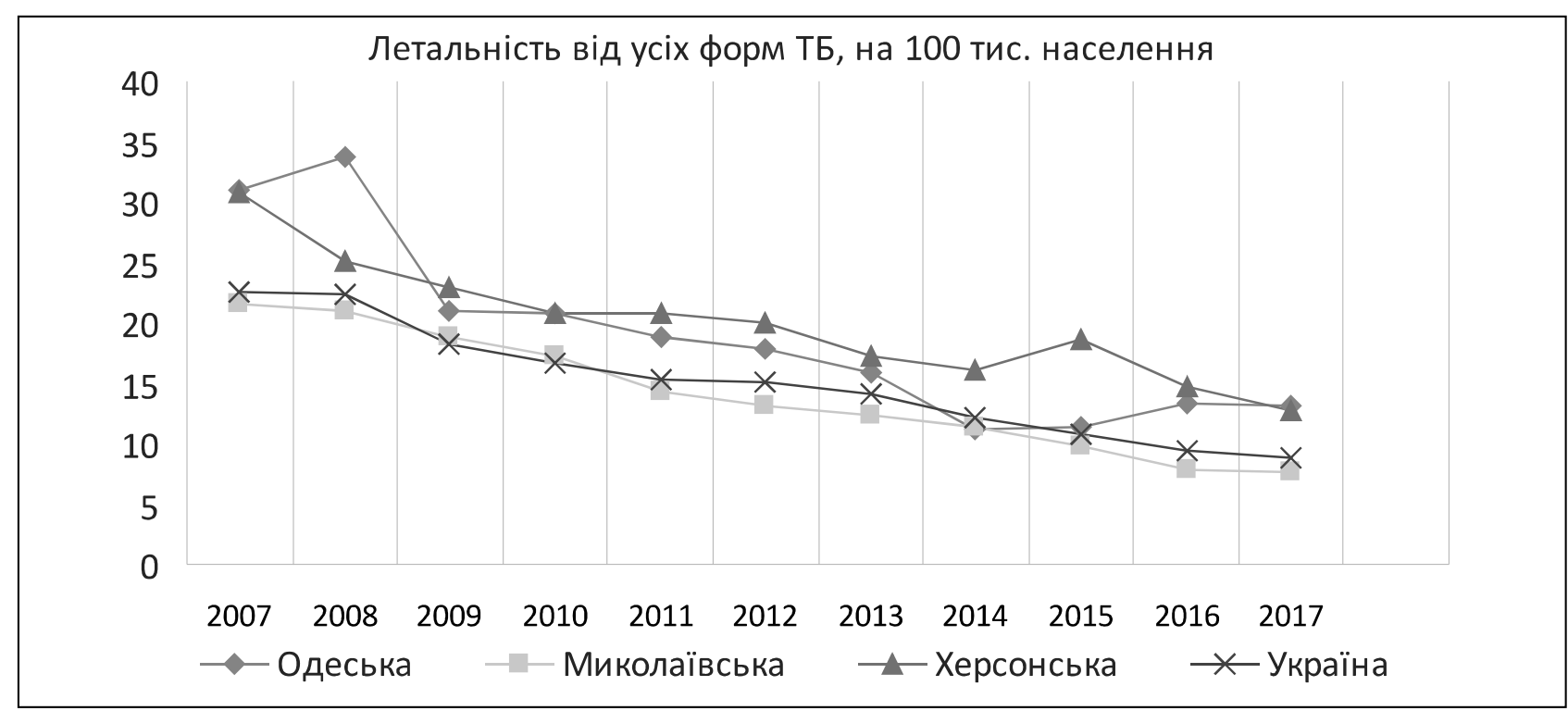

Рис. 9. Летальність від туберкульозу в Причорноморському регіоні України в період з 2007 до 2017 р.

Що стосується показника летальності від коінсрекції ТБ/ВІЛ, то пік його зростання в Україні припав на 2010-2012 рр., після чого розпочалося його зниження із середнім річним темпом $8,4 \%$ (табл. 6). В Одеській та Миколаївській областях, хоча і спостерігають певні коливання показників летальності від ТБ/ВІЛ, в цілому з 2015 р. прослідковується тенденція до їх зниження (рис. 10).

Таблиця 6. Летальність від усіх форм туберкульозу та кількість померлих хворих на туберкульоз від хвороби, зумовленої ВІЛ (ТБ/ВІЛ) в областях Причорноморського регіону України в період з 2006 до 2018 р.

\begin{tabular}{|c|c|c|c|c|c|c|c|c|}
\hline \multirow{3}{*}{ Рік } & \multicolumn{8}{|c|}{ Летальність по регіонах (абс., на 100 тис. населення) } \\
\hline & \multicolumn{2}{|c|}{ Одеська } & \multicolumn{2}{|c|}{ Миколаївська } & \multicolumn{2}{|c|}{ Херсонська } & \multicolumn{2}{|c|}{ Україна } \\
\hline & $\mathrm{TS}^{* 1}$ & ТБ/BIЛ*2 & $\mathrm{TE}^{\star 1}$ & ТБ/BІЛ*2 & $T \mathrm{~T}^{\star 1}$ & ТБ/BІЛ*2 & TБ*1 & ТБ/ВІЛ*2 \\
\hline 2006 & N/A & $\begin{array}{c}254 \\
(10,6)\end{array}$ & N/A & $\begin{array}{c}210 \\
(17,2)\end{array}$ & N/A & $\begin{array}{c}25 \\
(2,2)\end{array}$ & N/A & $\begin{array}{l}1606 \\
(3,4)\end{array}$ \\
\hline 2007 & $\begin{array}{c}739 \\
(31,0) \\
\end{array}$ & $\begin{array}{c}293 \\
(12,3) \\
\end{array}$ & $\begin{array}{c}261 \\
(21,6)\end{array}$ & $\begin{array}{c}208 \\
(17,2) \\
\end{array}$ & $\begin{array}{c}342 \\
(30,7)\end{array}$ & $\begin{array}{c}45 \\
(4,0) \\
\end{array}$ & $\begin{array}{l}10506 \\
(22,6) \\
\end{array}$ & $\begin{array}{l}1827 \\
(3,9) \\
\end{array}$ \\
\hline 2008 & $\begin{array}{c}806 \\
(33,8)\end{array}$ & $\begin{array}{c}311 \\
(13,0)\end{array}$ & $\begin{array}{c}253 \\
(21,0)\end{array}$ & $\begin{array}{c}287 \\
(23,9)\end{array}$ & $\begin{array}{c}278 \\
(25,1)\end{array}$ & $\begin{array}{c}42 \\
(3,8)\end{array}$ & $\begin{array}{l}10357 \\
(22,4) \\
\end{array}$ & $\begin{array}{l}2269 \\
(4,9)\end{array}$ \\
\hline
\end{tabular}


Продовження табл. 6

\begin{tabular}{|c|c|c|c|c|c|c|c|c|}
\hline \multirow{3}{*}{ Рік } & \multicolumn{8}{|c|}{ Летальність по регіонах (абс., на 100 тис. населення) } \\
\hline & \multicolumn{2}{|c|}{ Одеська } & \multicolumn{2}{|c|}{ Миколаївська } & \multicolumn{2}{|c|}{ Херсонська } & \multicolumn{2}{|c|}{ Україна } \\
\hline & $\mathrm{TE}^{\star 1}$ & $\mathrm{TБ} / \mathrm{BI} \int^{\star 2}$ & $T \mathrm{~T}^{\star 1}$ & $\mathrm{TБ} / \mathrm{BI} /^{\star 2}$ & $T \mathrm{~T}^{\star 1}$ & ТБ/BIЛ*2 & $T \mathrm{~T}^{\star 1}$ & $\overline{\mathrm{TБ} / \mathrm{BI} Л^{\star 2}}$ \\
\hline 2009 & $\begin{array}{c}501 \\
(21,0)\end{array}$ & $\begin{array}{c}278 \\
(11,7)\end{array}$ & $\begin{array}{c}226 \\
(18,9)\end{array}$ & $\begin{array}{c}219 \\
(18,3)\end{array}$ & $\begin{array}{c}252 \\
(23,0)\end{array}$ & $\begin{array}{c}47 \\
(4,3)\end{array}$ & $\begin{array}{l}8383 \\
(18,2)\end{array}$ & $\begin{array}{l}2539 \\
(5,5)\end{array}$ \\
\hline 2010 & $\begin{array}{c}494 \\
(20,8) \\
\end{array}$ & $\begin{array}{c}296 \\
(12,4) \\
\end{array}$ & $\begin{array}{c}206 \\
(17,3)\end{array}$ & $\begin{array}{c}199 \\
(16,7)\end{array}$ & $\begin{array}{c}227 \\
(20,8)\end{array}$ & $\begin{array}{c}53 \\
(4,9)\end{array}$ & $\begin{array}{c}7621 \\
(16,6)\end{array}$ & $\begin{array}{l}2749 \\
(6,0)\end{array}$ \\
\hline 2011 & $\begin{array}{c}446 \\
(18,8)\end{array}$ & $\begin{array}{c}333 \\
(14,0)\end{array}$ & $\begin{array}{c}171 \\
(14,4)\end{array}$ & $\begin{array}{c}171 \\
(14,5)\end{array}$ & $\begin{array}{c}226 \\
(20,8)\end{array}$ & $\begin{array}{c}71 \\
(6,5)\end{array}$ & $\begin{array}{c}6951 \\
(15,2)\end{array}$ & $\begin{array}{l}2765 \\
(6,1)\end{array}$ \\
\hline 2012 & $\begin{array}{c}422 \\
(17,8)\end{array}$ & $\begin{array}{c}340 \\
(14,3) \\
\end{array}$ & $\begin{array}{c}154 \\
(13,1)\end{array}$ & $\begin{array}{c}180 \\
(15,3) \\
\end{array}$ & $\begin{array}{c}216 \\
(20,0)\end{array}$ & $\begin{array}{c}55 \\
(5,1) \\
\end{array}$ & $\begin{array}{c}6862 \\
(15,1) \\
\end{array}$ & $\begin{array}{l}2786 \\
(6,1) \\
\end{array}$ \\
\hline 2013 & $\begin{array}{c}378 \\
(15,9)\end{array}$ & $\begin{array}{c}315 \\
(13,2) \\
\end{array}$ & $\begin{array}{c}144 \\
(12,3) \\
\end{array}$ & $\begin{array}{c}149 \\
(12,7) \\
\end{array}$ & $\begin{array}{c}185 \\
(17,2) \\
\end{array}$ & $\begin{array}{c}53 \\
(4,9) \\
\end{array}$ & $\begin{array}{c}6390 \\
(14,1) \\
\end{array}$ & $\begin{array}{l}2522 \\
(5,6) \\
\end{array}$ \\
\hline 2014 & $\begin{array}{c}265 \\
(11,1)\end{array}$ & $\begin{array}{c}292 \\
(12,2)\end{array}$ & $\begin{array}{c}133 \\
(11,4)\end{array}$ & $\begin{array}{c}129 \\
(11,0)\end{array}$ & $\begin{array}{c}172 \\
(16,1)\end{array}$ & $\begin{array}{c}41 \\
(3,8) \\
\end{array}$ & $\begin{array}{c}5240 \\
(12,2) \\
\end{array}$ & $\begin{array}{l}1994 \\
(4,6) \\
\end{array}$ \\
\hline 2015 & $\begin{array}{c}272 \\
(11,4)\end{array}$ & $\begin{array}{c}300 \\
(12,6)\end{array}$ & $\begin{array}{c}114 \\
(9,8)\end{array}$ & $\begin{array}{l}109 \\
(9,4)\end{array}$ & $\begin{array}{c}198 \\
(18,6)\end{array}$ & $\begin{array}{c}45 \\
(4,2)\end{array}$ & $\begin{array}{l}4602 \\
(10,8)\end{array}$ & $\begin{array}{l}1914 \\
(4,5)\end{array}$ \\
\hline 2016 & $\begin{array}{c}316 \\
(13,3)\end{array}$ & $\begin{array}{c}275 \\
(11,6)\end{array}$ & $\begin{array}{c}92 \\
(7,9)\end{array}$ & $\begin{array}{c}115 \\
(9,9)\end{array}$ & $\begin{array}{c}156 \\
(14,7)\end{array}$ & $\begin{array}{c}63 \\
(5,9)\end{array}$ & $\begin{array}{c}4064 \\
(9,5)\end{array}$ & $\begin{array}{l}1788 \\
(4,2)\end{array}$ \\
\hline 2017 & $\begin{array}{c}310 \\
(13,1)\end{array}$ & $\begin{array}{c}263 \\
(11,1)\end{array}$ & $\begin{array}{c}88 \\
(7,7)\end{array}$ & $\begin{array}{c}93 \\
(8,1)\end{array}$ & $\begin{array}{c}134 \\
(12,7)\end{array}$ & $\begin{array}{c}42 \\
(4,0)\end{array}$ & $\begin{array}{l}3735 \\
(8,8)\end{array}$ & $\begin{array}{l}1663 \\
(3,9)\end{array}$ \\
\hline 2018 & - & - & - & - & - & - & - & - \\
\hline
\end{tabular}

Примітки. «-» - дані відсутні; *1 - за даними Держстату України; *2 - дані використані з форми № 33-здоров «3віт про хворих на туберкульоз».

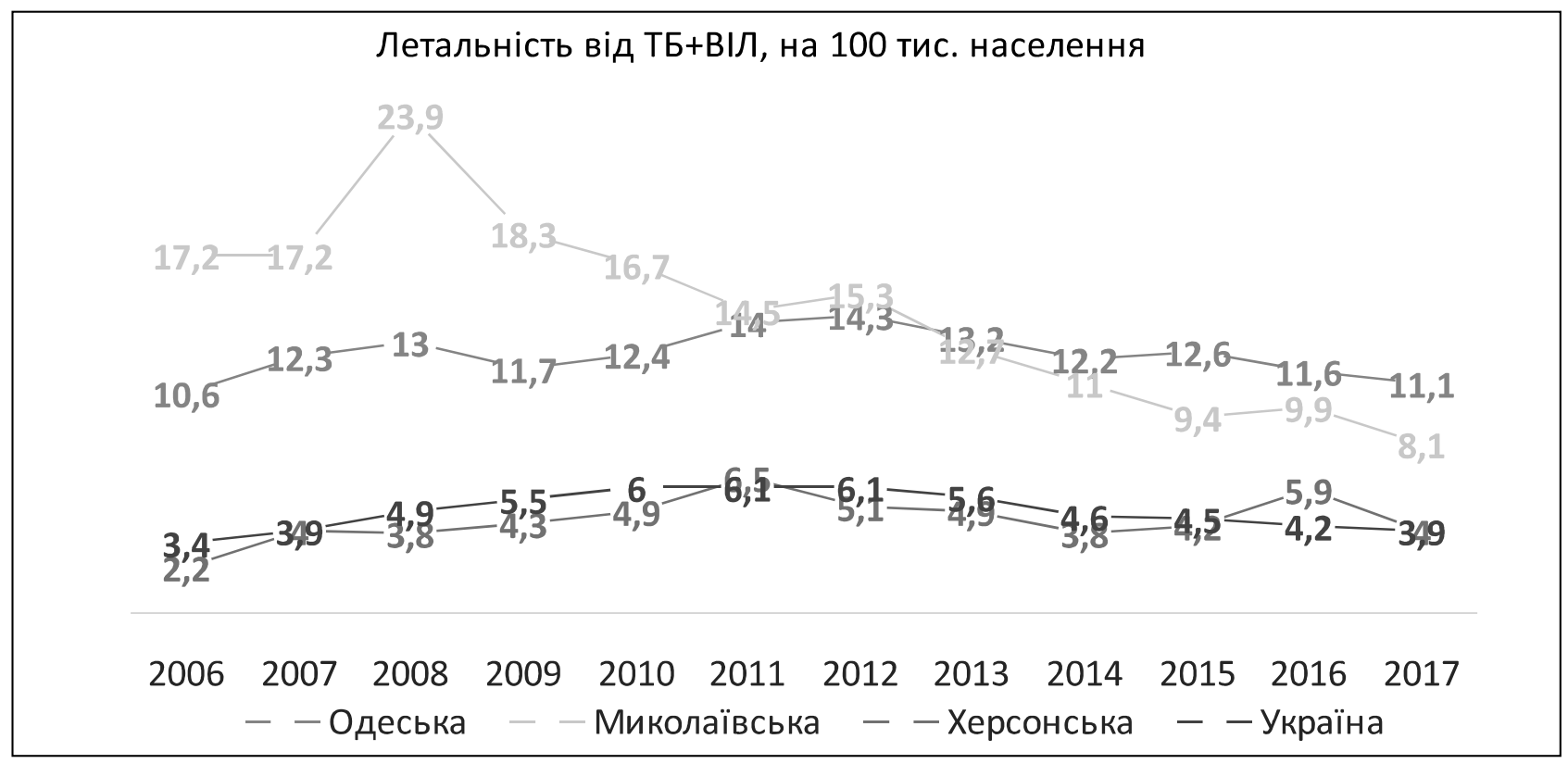

Рuc. 10. Летальність від ко-інфекції ВІЛ/ТБ у Причорноморському регіоні України в період 32006 до 2017 р.

Проте, летальність від ТБ/ВІЛ в Одеській та Миколаївській областях щороку перевищувала показник по Україні в середньому в 2,6 та 3,2 раза відповідно.

\section{Висновки}

1. 32012 р. в Україні спостерігають зниження захворюваності на туберкульоз (нові випадки та рецидиви), середній щорічний темп зниження становить 4,2 \%. За період з 2011 до 2018 р. у Миколаївській та Херсонській областях захворюваність на туберкульоз (нові випадки та рецидиви) зменшилася на 30,4 \% та 23,7 \% відповідно, а в Одеській області - зросла на $30,3 \%$.

2. 32007 до 2018 р. в Україні реєструють зниження захворюваності на нові випадки туберкульозу. Єдиною областю Причорноморського регіону, де було встановлено зростання захворюваності на вперше діагностований туберкульоз, стала Одеська - інтенсивний показник захворюваності за даний період часу тут збільшився на $24,4 \%$.

3. У 2017 р. на частку областей Причорноморського регіону України припадало 17 \% випадків 
мультирезистентного туберкульозу від загальної їх кількості в Україні.

4. За період 32011 до 2017 р. інтенсивний показник захворюваності на ко-інфекцію туберкульоз+ВІЛ зріс на 21 \%. Серед областей Причорноморського регіону найбільший щорічний середній темп приросту зафріксований в Одеській області - 13,5\%.

5. 32011 до 2017 р. такі епідеміологічні показники як захворюваність на туберкульоз (нові випадки та рецидиви), туберкульоз легень 3 бактеріовиділенням, вперше діагностований туберкульоз, мультирезистентний туберкульоз та ко-інфекцію туберкульоз+ВІЛ у кожній із областей Причорноморського регіону щороку перевищували відповідні середні показники по Україні. 32006 до 2017 р. поширеність активного туберкульозу в Україні скорочувалася в середньому на 8,7 \% за рік. Загальна тенденція до зниження поширеності туберкульозу простежується і в областях Причорноморського регіону. Лише в Одеській області з 2015 р. реєструють зростання поширеності туберкульозу, а з 2014 р. спостерігають досить стрімке зростання поширеності ко-інфекції
туберкульоз+ВІЛ, із середнім щорічним темпом приросту $16,3 \%$.

6. У Причорноморському регіоні та в Україні в цілому з 2012 до 2017 р. прослідковується тенденція до зниження летальності від туберкульозу. 3 початку 2016 р. приріст летальності від туберкульозу реєструють лише в Одеській області.

7. Пік зростання летальності від ко-інфекції туберкульоз+ВІЛ в Україні припав на 20102012 рр., після чого розпочалося його зниження із середнім річним темпом 8,4 \%. Незважаючи на коливання показників, з 2013 р. загальна тенденція до зниження летальності внаслідок коінфекції туберкульоз+ВІЛ простежувалася і в областях Причорноморського регіону. Проте летальність від туберкульоз+ВІЛ в Одеській та Миколаївській областях щороку перевищувала показник по Україні в середньому в 2,6 та 3,2 раза відповідно.

Перспективи подальших досліджень полягають у вивченні причин та наслідків поширеності мультирезистентного туберкульозу та ко-інфекції туберкульозу+ВІЛ.

\section{Список літератури}

1. ДУ «Центр громадського здоров'я Міністерства охорони здоров'я України». Таблиці зі статистичними даними за 2012 р. [Електронний ресурс]. - Режим доступу : https://phc.org.ua/sites/default/files/uploads/files/\%D0\%94\%D0\%9E\% D0\%92\%D0\%86\%D0\%94\%D0\%9D\%D0\%98\%D0\%9A_\%D0\%A2\%D0\%91_2012.xls.

2. ДУ «Центр громадського здоров'я Міністерства охорони здоров'я України». Таблиці зі статистичними даними за 2013 р. [Електронний ресурс]. - Режим доступу : https://phc.org.ua/sites/default/files/uploads/files/Dovidnik_ 2003-2013_20.05.2014.xls.

3. ДУ «Центр громадського здоров'я Міністерства охорони здоров'я України». Таблиці зі статистичними даними за 2014 р. [Електронний ресурс]. - Режим доступу : https://phc.org.ua/sites/default/files/uploads/files/\%D0\%A2\%D0\%B0\% D0\%B1\%D0\%BB\%D0\%B8\%D1\%86\%D1\%96\%20\%D0\%B7\%D1\%96\%20\%D1\%81\%D1\%82\%D0\%B0\%D1\%82\%D0\%B 8\%D1\%81\%D1\%82\%D0\%B8\%D1\%87\%D0\%BD\%D0\%B8\%D0\%BC\%D0\%B8\%20\%D0\%B4\%D0\%B0\%D0\%BD\%D0\%B 8\%D0\%BC\%D0\%B8.xls.

4. ДУ «Центр громадського здоров'я Міністерства охорони здоров'я України». Таблиці зі статистичними даними за 2016 р. [Електронний ресурс]. - Режим доступу : https://phc.org.ua/sites/default/files/uploads/files/\%20\% D0\%B7\%D1\%96\%20\%D1\%81\%D1\%82\%D0\%B0\%D1\%82\%D0\%B8\%D1\%81\%D1\%82\%D0\%B8\%D1\%87\%D0\%BD\% D0\%B8\%D0\%BC\%D0\%B8\%20\%D0\%B4\%D0\%B0\%D0\%BD\%D0\%B8\%D0\%BC\%D0\%B8\%20\%D0\%B7\%D0\%B0\%202016\%20\%D1\%80\%D1\%96\%D0\%BA.xls.

5. ДУ «Центр громадського здоров'я Міністерства охорони здоров'я України». Таблиці зі статистичними даними за 2017 р. [Електронний ресурс]. - Режим доступу : https://phc.org.ua/sites/default/files/uploads/files/\%20\% D0\%B7\%D1\%96\%20\%D1\%81\%D1\%82\%D0\%B0\%D1\%82\%D0\%B8\%D1\%81\%D1\%82\%D0\%B8\%D1\%87\%D0\%BD\% D0\%B8\%D0\%BC\%D0\%B8\%20\%D0\%B4\%D0\%B0\%D0\%BD\%D0\%B8\%D0\%BC\%D0\%B8\%20\%D0\%B7\%D0\%B0\%202017\%20\%D1\%80\%D1\%96\%D0\%BA._\%D0\%BE\%D1\%81\%D1\%82\%D0\%B0\%D1\%82\%D0\%BE\%D1\%87\%D0\%BD\%D 0\%B0\%201.xIs.

6. ДУ «Центр громадського здоров'я Міністерства охорони здоров'я України». Таблиці зі статистичними даними до аналітично-статистичного довідника «Туберкульоз в Україні» за 2015 р. [Електронний ресурс]. - Режим доступу : https://phc.org.ua/sites/default/files/uploads/files/\%20\%D0\%B4\%D0\%BE\%20\%D0\%B4\%D0\%BE\%D0\%B2\%D1\%96\%D0\%B 4\%D0\%BD\%D0\%B8\%D0\%BA\%D0\%B0\%20\%D0\%B7\%D0\%B0\%202015\%20\%D1\%80\%D1\%96\%D0\%BA.\%281\%29.xls.

7. ДУ «Центр громадського здоров'я Міністерства охорони здоров'я України». Туберкульоз в Україні (аналітичностатистичний довідник) 2018 [Електронний ресурс]. - Режим доступу : https://phc.org.ua/sites/default/files/uploads/fil es/\%D0\%BF\%D1\%80\%D0\%BE\%D0\%B5\%D0\%BA\%D1\%82\%20\%D0\%B4\%D0\%BE\%D0\%B2\%D1\%96\%D0\%B4\%D0\% BD\%D0\%B8\%D0\%BA\%D0\%B0\%20\%D0\%A2\%D0\%91\%202018.pdf.

8. ДЗ «Центр медичної статистики МОЗ України». Основні показники з туберкульозу за 2018 рік в порівнянні 3 аналогічним періодом 2017 року (згідно фрорми звітності № 8 «Звіт про захворювання на активний туберкульоз»).

9. Перельман М. И. Фтизиатрия : учебник / М. И. Перельман, В. А. Корякин, И. В. Богадельникова. - 2-е изд., перераб. и доп. - М. : Медицина, 2004. - 520 с. 
10. Global tuberculosis report 2018. World Health Organization 2018. ISBN 978-92-4-156564-6. URL : https://www.who. int/tb/publications/global_report/en/

11. World Health Organization: WHO. URL: https://www.who.int/en/news-room/fact-sheets/detail/tuberculosis

\section{References}

1. (2012). DU “Tsentr hromadskoho zdorovia Ministerstva okhorony zdorovia Ukrainy". Tablytsi zi statystychnymy danymy za 2012 r. [Public Health Center of the Ministry of Health of Ukraine. 2012 Tables of Statistics]. Retrieved from: https://phc. org.ua/sites/default/files/uploads/files/\%D0\%94\%D0\%9E\%D0\%92\%D0\%86\%D0\%94\%D0\%9D\%D0\%98\%D0\%9A_\%D0 $\%$ A2\%D0\%91_2012.xls

2. (2013). DU "Tsentr hromadskoho zdorovia Ministerstva okhorony zdorovia Ukrainy". Tablytsi zi statystychnymy danymy za 2013 r. [Public Health Center of the Ministry of Health of Ukraine. 2013 Tables of Statistics]. Retrieved from: https://phc. org.ua/sites/default/files/uploads/files/Dovidnik_2003-2013_20.05.2014.xls

3. (2014). DU "Tsentr hromadskoho zdorovia Ministerstva okhorony zdorovia Ukrainy. Tablytsi zi statystychnymy danymy za 2014 r. [Public Health Center of the Ministry of Health of Ukraine. 2014 Tables of Statistics]. Retrieved from: https:// phc.org.ua/sites/default/files/uploads/files/\%D0\%A2\%D0\%B0\%D0\%B1\%D0\%BB\%D0\%B8\%D1\%86\%D1\%96\%20 \%D0\%B7\%D1\%96\%20\%D1\%81\%D1\%82\%D0\%B0\%D1\%82\%D0\%B8\%D1\%81\%D1\%82\%D0\%B8\%D1\%87\%D0\%BD \%D0\%B8\%D0\%BC\%D0\%B8\%20\%D0\%B4\%D0\%B0\%D0\%BD\%D0\%B8\%D0\%BC\%D0\%B8.xls

4. (2016). DU "Tsentr hromadskoho zdorovia Ministerstva okhorony zdorovia Ukrainy". Tablytsi zi statystychnymy danymy za 2016 r. [Public Health Center of the Ministry of Health of Ukraine. 2016 Tables of Statistics]. Retrieved from: https://phc. org.ua/sites/default/files/uploads/files/\%20\%D0\%B7\%D1\%96\%20\%D1\%81\%D1\%82\%D0\%B0\%D1\%82\%D0\%B8\%D1\% 81\%D1\%82\%D0\%B8\%D1\%87\%D0\%BD\%D0\%B8\%D0\%BC\%D0\%B8\%20\%D0\%B4\%D0\%B0\%D0\%BD\%D0\%B8\%D0\% BC\%D0\%B8\%20\%D0\%B7\%D0\%B0\%202016\%20\%D1\%80\%D1\%96\%D0\%BA.xls

5. (2017). DU Tsentr hromadskoho zdorovia Ministerstva okhorony zdorovia Ukrainy". Tablytsi zi statystychnymy danymy za 2017 r. [Public Health Center of the Ministry of Health of Ukraine. 2017 Tables of Statistics]. Retrieved from: https://phc. org.ua/sites/default/files/uploads/files/\%20\%D0\%B7\%D1\%96\%20\%D1\%81\%D1\%82\%D0\%B0\%D1\%82\%D0\%B8\%D1\% 81\%D1\%82\%D0\%B8\%D1\%87\%D0\%BD\%D0\%B8\%D0\%BC\%D0\%B8\%20\%D0\%B4\%D0\%B0\%D0\%BD\%D0\%B8\%D0\% BC\%D0\%B8\%20\%D0\%B7\%D0\%B0\%202017\%20\%D1\%80\%D1\%96\%D0\%BA._\%D0\%BE\%D1\%81\%D1\%82\%D0\%B0 \%D1\%82\%D0\%BE\%D1\%87\%D0\%BD\%D0\%B0\%201.xls

6. (2015). DU Tsentr hromadskoho zdorovia Ministerstva okhorony zdorovia Ukrainy". Tablytsi zi statystychnymy danymy do analitychno-statystychnoho dovidnyka "Tuberkuloz v Ukraini" za $2015 \mathrm{r}$. [Public Health Center of the Ministry of Health of Ukraine. Tables with statistics to the analytical and statistical reference "Tuberculosis in Ukraine" for 2015]. Retrieved from: https://phc.org.ua/sites/default/files/uploads/files/\%20\%D0\%B4\%D0\%BE\%20\%D0\%B4\% D0\%BE\%D0\%B2\%D1\%96\%D0\%B4\%D0\%BD\%D0\%B8\%D0\%BA\%D0\%B0\%20\%D0\%B7\%D0\%B0\%202015\%20 \%D1\%80\%D1\%96\%D0\%BA.\%281\%29.xls

7. (2018). DU "Tsentr hromadskoho zdorovia Ministerstva okhorony zdorovia Ukrainy. Tuberkuloz v Ukraini (analitychnostatystychnyi dovidnyk) 2018 [Public Health Center of the Ministry of Health of Ukraine. Tuberculosis in Ukraine (analytical and statistical reference) 2018]. Retrieved from: https://phc.org.ua/sites/default/files/uploads/files/\%D0\%BF\%D1\%80\%D0 \%BE\%D0\%B5\%D0\%BA\%D1\%82\%20\%D0\%B4\%D0\%BE\%D0\%B2\%D1\%96\%D0\%B4\%D0\%BD\%D0\%B8\%D0\%BA\%D 0\%B0\%20\%D0\%A2\%D0\%91\%202018.pdf

8. (2018). DZ "Tsentr medychnoi statystyky MOZ Ukrainy". Osnovni pokaznyky z tuberkulozu za 2018 rik v porivnianni z analohichnym periodom 2017 roku (zhidno formy zvitnosti № 8 "Zvit pro zakhvoriuvannia na aktyvnyi tuberkuloz") [State Medical Center of the Ministry of Health of Ukraine. Key tuberculosis indicators for 2018 compared to the same period in 2017 (according to the report form No. 8 "Report on active tuberculosis")].

9. Perelman, M.I., Koriakin, V.A., \& Bogadelnikova, I.V. (2004). Ftiziziatriya [Phthisiology]. Moscow: Meditsina [in Russian]. 10. Global tuberculosis report 2018. World Health Organization 2018. ISBN 978-92-4-156564-6. Retrieved from: https:// www.who.int/tb/publications/global_report/en/

11. World Health Organization: WHO. Retrieved from: https://www.who.int/en/news-room/fact-sheets/detail/tuberculosis

\section{ДИНАМИКА ИЗМЕНЕНИЙ ЭПИДЕМИЧЕСКОЙ СИТУАЦИИ ПО ТУБЕРКУЛЕЗУ В ОБЛАСТЯХ ПРИЧЕРНОМОРСКОГО РЕГИОНА И В УКРАИНЕ В ПЕРИОД С 2006 ПО 2018 Г.}

К. А. Талалаев, В. С. Гойдык, Р. С. Вастьянов, А. В. Тодорова

Одесский национальный медицинский университет, г. Одесса, Украина

Цель: проанализировать эпидемическую ситуацию по туберкулезу в Украине и, в частности, в Причерноморском регионе (Одесская, Николаевская и Херсонская области) в период с 2006 по 2018 г. по показателям заболеваемости (новые случаи и рецидивы туберкулеза), туберкулез легких с бактериовыделением, мультирезистентным туберкулезом и ко-иноекцией туберкулез+ВИЧ, а также распространенности и летальности от туберкулеза и ко-инфекции туберкулез+Вич.

Материалы и методы. Для проведения данного исследования использованы аналитико-статистические материалы по туберкулезу, обнародованные на официальном сайте Центра общественного здоровья МЗ Украины.

Результаты. С 2012 г. заболеваемость туберкулезом в Украине ежегодно снижалась в среднем на 4,2\%. Однако в Одесской области в период с 2011 по 2018 г. заболеваемость туберкулезом выросла на 30,3 \%. Интенсивный показатель заболеваемости ко-инфекцией туберкулез+ВИЧ в Украине увеличился 
на 21 \% в период с 2011 по 2017 г. Снижение распространенности и летальности от туберкулеза в Украине наблюдают с 2006 по 2017 г. и с 2012 по 2017 г. соответственно.

Выводы. С 2011 по 2017 г. заболеваемость туберкулезом (новые случаи и рецидивы), туберкулез легких с бактериовыделением, впервые диагностированный туберкулез, мультирезистентный туберкулез и ко-инфекция туберкулез+Вич в Одесской, Николаевской и Херсонской областях ежегодно превышали соответствующие средние показатели по Украине.

В Причерноморском регионе, за исключением Одесской области, и в Украине в целом с 2012 по 2017 г. прослеживается тенденция к снижению летальности от туберкулеза.

Летальность от ко-инфекции туберкулез+ВИЧ в Одесской и Николаевской областях ежегодно превышала показатель по Украине в среднем в 2,6 и 3,2 раза соответственно.

КЛЮЧЕВЫЕ СЛОВА: туберкулез; бактериовыделение; мультирезистентный туберкулез; коинфекция туберкулез+ВИЧ, распространенность; летальность; Причерноморский регион Украины.

\section{DYNAMICS OF EPIDEMIC SITUATION CHANGES WITH TUBERCULOSIS IN THE BLACK SEA REGIONS AND IN UKRAINE DURING 2006-2018}

K. O. Talalayev, V. S. Goidyk, R. S. Vastyanov, A. V. Todorova

Odesa National Medical University, Odesa, Ukraine

Purpose: to analyze the epidemiological situation of tuberculosis in Ukraine and in particular in the Black Sea region (Odesa, Mykolaiv and Kherson regions) from 2006 to 2018 using the following indicators: the incidence of tuberculosis (new and previously treated cases), pulmonary tuberculosis with bacteria excretion, multidrug resistant tuberculosis, tuberculosis + HIV co-infection; prevalence of tuberculosis and tuberculosis + HIV coinfection; tuberculosis and tuberculosis + HIV co-infection mortality.

Materials and Methods. The analytical-statistical materials regarding tuberculosis infection published on the Centre of Public Health of the Ministry of Health of Ukraine official website were used for the current research.

Results. Since 2012 the incidence of tuberculosis in Ukraine has been decreasing at an annual average rate of $4.2 \%$. However, in Odesa region the incidence of tuberculosis has increased by 30.3\% from 2011 to 2018. From 2011 to 2017 the intensive indicator of the incidence of tuberculosis + HIV co-infection in Ukraine had increased by $21 \%$. The decrease in tuberculosis prevalence and mortality from tuberculosis in Ukraine had been observed from 2006 to 2017 and from 2012 to 2017 respectively.

Conclusions. From 2011 to 2017 such epidemiological indicators as the incidence of tuberculosis (new and previously treated cases), pulmonary tuberculosis with bacteria excretion, multidrug resistant tuberculosis, tuberculosis + HIV co-infection in Odesa, Mykolaiv and Kherson regions were significantly higher than the average values in Ukraine.

From 2012 to 2017 tuberculosis mortality rate in Ukraine and specifically in Mykolaiv and Kherson regions had been falling down. In Odesa and Mykolaiv regions the tuberculosis + HIV co-infection mortality rate each year was 2.6 and 3.2 times respectively higher than the average value in Ukraine.

KEY WORDS: tuberculosis; bacterial excretion; multidrug resistant tuberculosis; co-infection with tuberculosis + HIV, prevalence; mortality; Black Sea region of Ukraine.

Рукопис надійшов до редакції 04.07.2019 р.

\section{Відомості про авторів:}

Талалаєв Костянтин Олександрович - проректор Одеського національного медичного університету, кафедра соціальної медицини, громадського здоров'я та медичного права Одеського національного медичного університету; тел.: +38(048) 728-54-21.

Гойдик Віктор Степанович - доктор медичних наук, професор, профресор кафедри клінічної імунології, генетики і медичної біології Одеського національного медичного університету; тел.: +38(048) 712-31-19.

Вастьянов Руслан Сергійович - доктор медичних наук, профресор, завідувач кафедри загальної та клінічної патологічної фрізіології імені В. В. Підвисоцького Одеського національного медичного університету; тел.: +38(048) 711-72-54.

Тодорова Аліна В'ячеславівна - кандидат медичних наук, асистент кафредри гістології, цитології та ембріології Одеського національного медичного університету; тел.: +38(048) 712-31-18. 